\title{
Screening of candidate regulators for cellulase and hemicellulase production in Trichoderma reesei and identification of a factor essential for cellulase production
}

\author{
Mari Häkkinen", Mari J Valkonen, Ann Westerholm-Parvinen, Nina Aro, Mikko Arvas, Marika Vitikainen, \\ Merja Penttilä, Markku Saloheimo and Tiina M Pakula
}

\begin{abstract}
Background: The soft rot ascomycetal fungus Trichoderma reesei is utilized for industrial production of secreted enzymes, especially lignocellulose degrading enzymes. T. reesei uses several different enzymes for the degradation of plant cell wall-derived material, including 9 characterized cellulases, 15 characterized hemicellulases and at least 42 genes predicted to encode cellulolytic or hemicellulolytic activities. Production of cellulases and hemicellulases is modulated by environmental and physiological conditions. Several regulators affecting the expression of cellulase and hemicellulase genes have been identified but more factors still unknown are believed to be present in the genome of $T$. reesei.

Results: We have used transcriptional profiling data from $T$. reesei cultures in which cellulase/hemicellulase production was induced by the addition of different lignocellulose-derived materials to identify putative novel regulators for cellulase and hemicellulase genes. Based on this induction data, supplemented with other published genome-wide data on different protein production conditions, 28 candidate regulatory genes were selected for further studies and they were overexpressed in T. reesei. Overexpression of seven genes led to at least 1.5 -fold increased production of cellulase and/or xylanase activity in the modified strains as compared to the parental strain. Deletion of gene 77513 , here designated as ace3, was found to be detrimental for cellulase production and for the expression of several cellulase genes studied. This deletion also significantly reduced xylanase activity and expression of xylan-degrading enzyme genes. Furthermore, our data revealed the presence of co-regulated chromosomal regions containing carbohydrate-active enzyme genes and candidate regulatory genes.

Conclusions: Transcriptional profiling results from glycoside hydrolase induction experiments combined with a previous study of specific protein production conditions was shown to be an effective method for finding novel candidate regulatory genes affecting the production of cellulases and hemicellulases. Recombinant strains with improved cellulase and/or xylanase production properties were constructed, and a gene essential for cellulase gene expression was found. In addition, more evidence was gained on the chromatin level regional regulation of carbohydrate-active enzyme gene expression.
\end{abstract}

Keywords: Carbohydrate active enzymes, Cellulase, Co-regulation, Gene regulation, Hemicellulase, Transcription factors, Transcriptional profiling

\footnotetext{
* Correspondence: mari.hakkinen@vtt.fi

VTT Technical Research Centre of Finland, PO Box 1000 Tietotie 2, Espoo
} FI-02044, VTT, Finland

\section{Ciomed Central}

(c) 2014 Häkkinen et al.; licensee BioMed Central Ltd. This is an Open Access article distributed under the terms of the Creative Commons Attribution License (http://creativecommons.org/licenses/by/2.0), which permits unrestricted use, distribution, and reproduction in any medium, provided the original work is properly credited. 


\section{Background}

Plant biomass, consisting mostly of cellulose, hemicellulose and lignin, is the most abundant renewable energy source on earth. Degradation of the biomass and continuation of the carbon cycle is maintained mainly by microbial action, especially by fungi of different species. The biomass-degrading enzymes produced by these organisms also have applications in different fields of industry, including biorefinery applications [1]. Trichoderma reesei (an anamorph of Hypocrea jecorina) is an extremely efficient producer of cellulose- and hemicellulose-degrading enzymes, and is therefore widely employed by the enzyme industry for the production of its own enzymes as well as for producing proteins from other sources $[2,3]$. The genome of $T$. reesei encodes nine characterized cellulase enzymes and 15 characterized hemicellulase enzymes. In addition, a large number of genes encoding candidate carbohydrate-active enzymes (CAZy) [4,5] have been identified from the genome [6,7]. According to an updated annotation, the genome encodes 201 glycoside hydrolase genes, 22 carbohydrate esterase genes and 5 polysaccharide lyase genes, of which at least 66 are known or predicted to encode cellulolytic and hemicellulolytic activities [8].

Energy efficient production of cellulases and hemicellulases is achieved by tight gene regulation governed by inducer-dependent expression of the genes and by repression of the genes in the presence of fast metabolized carbon sources (for reviews see $[9,10]$ ). In addition to the type of carbon source, additional environmental conditions are known to affect protein production together with the physiological state of the cells, such as $\mathrm{pH}$ [11], light [12], the specific growth rate and cell density of the fungus $[13,14]$, and the physiological state of the mitochondria [15]. Furthermore, the expression of many cellulase and hemicellulase genes is shown to be under a feedback regulation mechanism that functions under conditions in which the capacity of the cells to fold and secrete proteins is limited and transcriptional downregulation is required to reduce the amount of secreted protein produced [16].

The variety of environmental and physiological factors affecting the enzyme production of $T$. reesei infers that a complex signaling cascade and regulatory network is needed for the accurate timing of hydrolytic enzyme production. Several regulatory factors for cellulase and hemicellulase genes have been characterized, the most extensively studied of which are the transcription factor CRE1, which mediates carbon catabolite repression [17], and the major regulator needed for expression, XYR1 [18]. Other characterized factors are the positively acting ACE2 [19] and HAP2/3/5 complex [20], and the negatively acting factor ACE1 [21,22]. Recently, novel factors possibly affecting the regulation of genes encoding hydrolytic enzymes have been found from Trichoderma and other fungi. F-box proteins that have been suggested to be involved in the regulation of plant cell walldegrading enzymes have been identified from Aspergillus and Fusarium [23,24]. Two putative regulators of cellulase and hemicellulase genes named CLR-1 and CLR-2 have been identified from Neurospora crassa [25] and a transcription factor BglR has been suggested to regulate $\beta$ glucosidase genes of T. reesei [26]. Another recent finding is that the putative methyltransferase LAE1 is essential for the formation of $T$. reesei cellulases and hemicellulases, although the precise mechanism is still unclear [27]. In the light of recent findings from Trichoderma and other fungi, it can be assumed that not all regulatory factors have been identified yet and that additional regulatory genes can still be found in the genome of T. reesei.

In this study, transcriptional profiling data from $T$. reesei cultivated in the presence of several lignocellulose substrates as well as other genome-wide data from different types of protein production conditions were used to identify putative regulators for cellulase and hemicellulase genes. Several candidate regulatory genes were identified, and shown to have an effect on cellulase and hemicellulase production when overexpressed in $T$. reese $i$. Furthermore, the genomic context of the CAZy genes and co-regulated candidate regulatory genes were analyzed. The data revealed co-regulated regions containing candidate regulatory genes and CAZy genes, as well as other genes relevant for the utilization of the carbon source, such as transporter genes. The relevance of the regions is discussed in the paper.

\section{Results}

Analysis of transcriptome data to identify candidates for regulators of cellulase and hemicellulase genes

Transcriptome analysis has previously been carried out to study the expression of CAZy genes in T. reesei cultures that were induced by the addition of different types of lignocellulose material, purified carbohydrate polymers or disaccharides (Avicel cellulose, pretreated wheat straw, pretreated spruce or sophorose) [8]. In the present study, data from the previous work were further analyzed and explored to identify candidate regulators for CAZy genes and, in particular, for cellulase and hemicellulase genes. The expression data were clustered using Mfuzz [28,29] to reveal groups of co-regulated genes. The majority of the genes encoding characterized enzymes and accessory factors involved in lignocellulose degradation were found in two clusters. Cluster 10 contained the major cellulase and $\beta$-glucosidase genes (cbh1, cbh2, egl1, egl2, egl3, egl5, bgl1 and bgl2) together with a set of hemicellulase genes (abf1, bga1, cip2, cel74a and xyn3). Cluster 35 contained predominantly hemicellulase genes (agl1, agl3, man1, aes1, axe1, bxl1, glr1, xyn1 and xyn4) (Figure 1; for gene names, see [8]). 


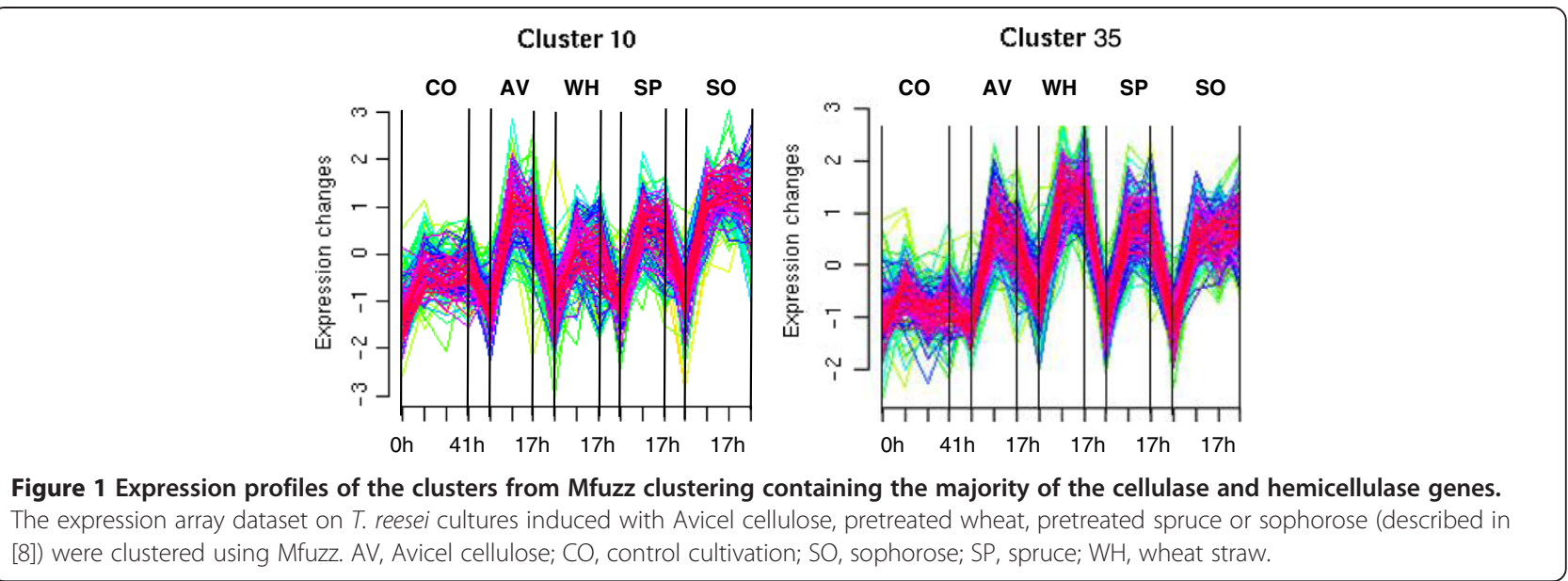

Only a few characterized hemicellulase genes were found outside these clusters ( $\alpha$-galactosidase genes 1 and 2, and xylanase 2 gene). A large number of putative regulatory genes clustered together with the known cellulase and hemicellulase genes. In particular, many genes encoding putative fungal C6 zinc finger-type transcription factors (containing InterPro domains IPR001138 fungal transcriptional regulatory protein, N-terminal and/or IPR007219 transcription factor, fungi [30]) were enriched within the clusters $(P=0.00027)$. Within the clusters, $5.9 \%$ of the genes encoded the predicted fungal type transcription factors, whereas only $2.5 \%$ of the total genome content belonged to this class. In addition, the clusters contained genes encoding candidates for other types of Zinc finger proteins, kinases and proteins involved in chromatin remodeling or organization, as well as proteins with InterPro domains indicating different regulatory or signal transduction functions (for the classes of the genes, see Table 1). A few known regulators were among the co-expressed genes, such as xyr1, the major regulator for cellulase and hemicellulase expression [18], and the homologues for N. crassa clr-2 [25], Aspergillus nidulans creC [31] and Fusarium oxysporum frp1 [24].

To cover putative regulatory genes induced by the substrates but showing different temporal patterns and extent of induction (and therefore not clustered together with the characterized cellulase and hemicellulase genes), the differentially expressed genes at each of the time points were identified by comparing the expression level in the induced cultures to the level in the uninduced control cultures (using Limma package ( $\mathrm{R}$, Bioconductor) $[28,32]$, and the cut-off $P<0.01$ in the statistical analysis). Altogether, 89 genes with putative regulatory functions were either co-clustered with the characterized cellulase and hemicellulase genes or showed increased signal level in most of the inducing conditions studied.

In order to get further support for the relevance of the 89 candidate genes in cellulase and hemicellulase production and to narrow down the number of genes to be selected for further studies, the expression of the candidate genes was compared in additional datasets on different protein production conditions. Transcriptome and proteome data from chemostat cultures with different specific growth rate, cell density and specific protein production rate [14] were explored for expression of the candidate genes and production of the corresponding proteins. Expression of 14 candidate genes showed either positive or negative correlation (absolute value $<0.5$ ) to the specific protein production rate in the chemostat cultures. Proteome analysis of the same cultures [14] showed that the candidate GCN5-related N-acetyltransferase (123668) was more abundant in the cultures with higher protein (and cellulase) production level, whereas the SEC14-domain protein 81972 and the candidate GCN5related N-acetyltransferase (120120) were more abundant in the cultures with low protein (cellulase) production. The results are in accordance with the positive and negative correlation of the expression of genes 123668 and 81972 with the specific protein production rate, respectively. Gene 120120 showed a slightly negative correlation with the specific protein production rate.

The CAZy genes are not randomly positioned in the genome. It has been reported that $41 \%$ of CAZy genes are found in 25 discrete regions ranging from $14 \mathrm{~kb}$ to $275 \mathrm{~kb}$ in length, and cases of co-expressed adjacent or nearly adjacent genes have been shown [7]. The regions of high CAZy gene density were found to contain genes encoding proteins involved in secondary metabolism. Our study also revealed the presence of regulatory genes in close vicinity to CAZy genes. In some cases, coexpression of these regulatory genes with CAZy genes was also detected. This information was used in the selection of candidate regulatory genes for further studies. For example, genes 76677 and 121130 are located in a broad, partly co-regulated region containing several CAZy genes. These genes include a candidate GH27 $\alpha$-galactosidase 
Table 1 Classes, functional domains and domain descriptions of the candidate regulators encoded by the genes that are co-regulated with cellulase and/or hemicellulase genes

\begin{tabular}{|c|c|c|c|}
\hline Class & $\begin{array}{l}\text { InterPro } \\
\text { domain }\end{array}$ & Domain description & $\begin{array}{l}\text { Candidate } \\
\text { regulatory } \\
\text { genes }\end{array}$ \\
\hline \multirow[t]{2}{*}{ Fungal transcription factors (Zn2-C6 type) } & IPR001138 & Fungal transcriptional regulatory protein, $\mathrm{N}$-terminal & 31 \\
\hline & IPR007219 & Transcription factor, fungi & \\
\hline \multirow[t]{2}{*}{ Transcription factors, basic-leucine zipper type } & IPR004827 & Basic-leucine zipper transcription factor & 1 \\
\hline & IPR011616 & Basic-leucine zipper transcription factor, bZIP-1 & \\
\hline Transcription factor, Tcf25 type repressor & IPR006994 & Transcription factor 25 & 1 \\
\hline Zinc finger, $\mathrm{C} 2 \mathrm{H} 2$ type & IPR007087 & Zinc finger, $\mathrm{C} 2 \mathrm{H} 2$-type & 2 \\
\hline \multirow[t]{5}{*}{ Zinc finger, other types } & IPR002893 & Zinc finger, MYND-type & 1 \\
\hline & IPR000058 & Zinc finger, AN1-type & 1 \\
\hline & IPR002867 & Zinc finger, C6HC-type & 1 \\
\hline & IPR008913 & Zinc finger, $\mathrm{CHY}$-type & 1 \\
\hline & IPR000571 & Zinc finger, CCCH-type & 1 \\
\hline \multirow[t]{10}{*}{ Chromatin level regulation/remodeling } & IPR013256 & Chromatin SPT2 & 1 \\
\hline & IPR000953 & Chromo domain & 1 \\
\hline & IPR008251 & Chromo shadow & \\
\hline & IPR000182 & GCN5-related N-acetyltransferase & 6 \\
\hline & IPR013178 & Histone H3-K56 acetyltransferase, RTT109 & 1 \\
\hline & IPR001214 & SET domain & 2 \\
\hline & IPR000330 & SNF2-related & 1 \\
\hline & IPR001025 & Bromo adjacent homology domain & 1 \\
\hline & IPR001487 & Bromodomain & 1 \\
\hline & IPR000210 & BTB/POZ-like & \\
\hline \multirow[t]{2}{*}{ Protein kinases } & IPR000719 & Protein kinase, catalytic domain & 7 \\
\hline & IPR011009 & Protein kinase-like domain & \\
\hline \multirow[t]{4}{*}{ G protein signaling } & IPR011021 & Arrestin-like, N-terminal & 1 \\
\hline & IPR011022 & Arrestin-like, C-terminal & \\
\hline & IPR000832 & G protein-coupled reseptor, family 2, secretin-like & 1 \\
\hline & IPR000342 & Regulator of $\mathrm{G}$ protein signaling & 2 \\
\hline \multirow[t]{15}{*}{ Other regulators } & IPR000095 & PAK-box/P21-Rho-binding & \\
\hline & IPR000387 & Dual-specific/protein-tyrosine phosphatase, conserved region & 1 \\
\hline & IPR000791 & GPR1/FUN34/yaaH & 1 \\
\hline & IPR009057 & Homeodomain-like & 1 \\
\hline & IPR001611 & Leucine-rich repeat & 1 \\
\hline & IPR008030 & NmrA-like & 1 \\
\hline & IPR008914 & Phosphatidylethanolamine-binding protein & 1 \\
\hline & IPR012093 & Pirin & 2 \\
\hline & $\underline{\text { IPR011989 }}$ & Armadillo-like helical & 2 \\
\hline & IPR001313 & Pumilio RNA-binding repeat & \\
\hline & IPR001251 & CRAL-TRIO domain & 1 \\
\hline & IPR005511 & Senescence marker protein-30 & 1 \\
\hline & IPR001810 & F-box domain, cyclin-like & 1 \\
\hline & IPR003892 & Ubiquitin system component Cue & 1 \\
\hline & IPR001680 & WD40 repeat & 4 \\
\hline
\end{tabular}


gene (59391), a candidate GH2 $\beta$-mannosidase gene (59689) and characterized $\beta$-glucosidase (bgll) and $\beta$-xylosidase (bxl1) genes (data not shown). Gene 102499 has an interesting location between a very tightly co-regulated region of CAZy genes and putative secondary metabolism genes (Figure 2, region 1). Gene 120120 is located in a coexpressed region including four genes of the hemicellulase gene-enriched cluster (cluster 35), and close to a second co-expressed region containing the candidate regulatory genes 74765, 55422 and the repressor gene cre1 (Figure 2, region 2).
Interestingly, we found several loci where a $\beta$ glucosidase and/or putative sugar transporter gene is located next to a gene with a putative regulatory function and co-expressed with it. Genes 77513, 105263 and 121121 are located next to candidate $\beta$-glucosidase genes cel1b, cel3e and cel3d, respectively. The regions including genes 77513, 121121 and 26163 (the closest homologue for $N$. crassa clr-2) contain a putative sugar transporter gene (Figure 2).

The focus in selection of candidate regulatory genes for further studies was on the genes encoding putative

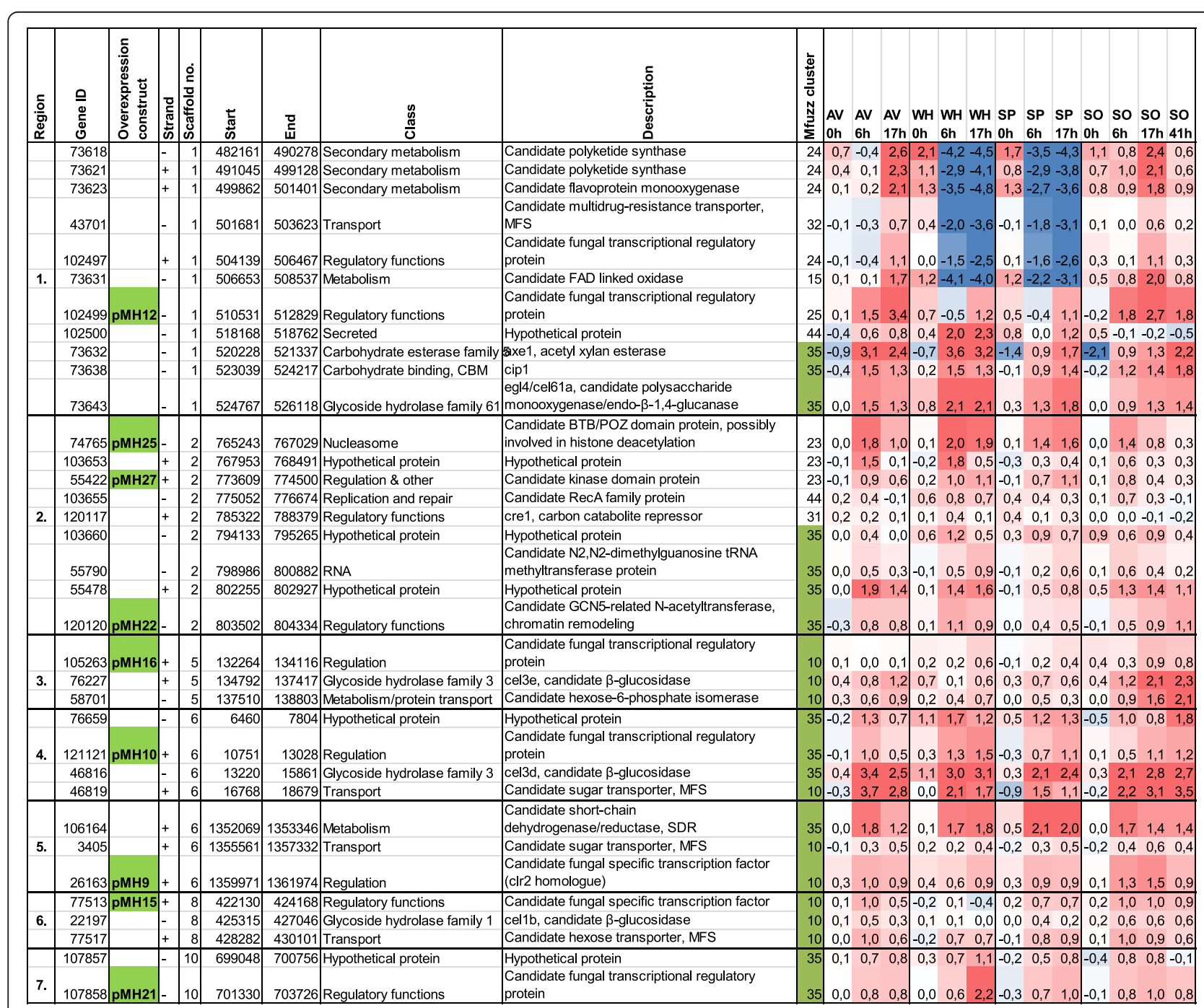

Figure 2 Tightly co-expressed genomic regions with candidate regulatory genes. The expression array dataset described in [8] was searched for genomic regions with co-expressed genes. The regions containing a selected candidate regulatory gene with adjacent genes belonging to the same Mfuzz gene expression clusters as the major cellulase and hemicellulase genes are shown. The genomic location of the genes is indicated as scaffold number, start and end position, and strand in the scaffold as in T. reesei database 2.0 [45]. Gene annotation is as in T. reesei database 2.0. The expression data of the genes in the induction dataset with cellulose, wheat and spruce material, and sophorose is shown as the expression cluster number (Mfuzz) and fold change of the transcript signals in the induced cultures as compared to the uninduced control cultures at the same time point. The intensity of the red color and blue color indicates the strength of positive and negative fold changes as compared to the uninduced control cultures, respectively. AV, Avicel cellulose; SO, sophorose; SP, spruce; WH, wheat straw. 
transcription factors. The selected genes fulfilled several of the following criteria: induction by three or more of the cellulase- or hemicellulase-inducing substrates used in the study; co-clustering with the characterized cellulase and hemicellulase genes in the Mfuzz clustering of the expression data; correlation of the expression signal with specific protein production rate in the chemostat study [14]; increased signal of the corresponding protein under good protein-producing conditions in proteome analysis of the chemostat cultures [14]; and co-localization with cellulase and hemicellulase genes in the genome and, preferably, also co-expression of the co-localized genes. In addition, representatives of genes with functional domains indicating different regulatory functions and fulfilling the same criteria were selected. Altogether 28 genes were selected for further studies (Table 2).

The expression profiles of the selected candidate regulatory genes together with characterized cellulase and hemicellulase genes are represented as a heatmap in Figure 3. The heatmap shows fold change data of the signals in the induced cultures versus the signals in the uninduced cultures at the corresponding time points. Expression values of an additional dataset on cultures induced with a broader set of lignocellulose material (differently pretreated bagasse, oat spelt and birch xylans [8]) are also included. In the heatmap, the candidate regulatory genes are divided into three major groups. Genes 122523, 80291, 74765 and 123668 are co-expressed together with the gene cluster containing many of the known hemicellulase genes (cluster 35 ). The genes are moderately induced in the presence of the majority of the substrates used, but especially on wheat and spruce. The second group of candidate regulatory genes showed modest induction by the majority of the substrates (IDs 73792, 107858, 70351, 121130, 123019, 62244, 55422, 76677, 121121 and 56077). The third group clusters together with many of the

Table 2 Putative regulatory genes chosen for further studies and the functional domains present in the encoded proteins

\begin{tabular}{|c|c|c|c|}
\hline Gene ID & Construct & InterPro ID & Description \\
\hline 108381 & $\mathrm{pMH8}$ & IPR001138 & Fungal transcriptional regulatory protein, $\mathrm{N}$-terminal \\
\hline 26163 & $\mathrm{pMH9}$ & IPR001138, IPR007219 & Fungal transcriptional regulatory protein, N-terminal; Transcription factor, fungi \\
\hline 121121 & $\mathrm{pMH10}$ & IPR001138 & Fungal transcriptional regulatory protein, $\mathrm{N}$-terminal \\
\hline 70351 & $\mathrm{pMH11}$ & IPR001138 & Fungal transcriptional regulatory protein, $\mathrm{N}$-terminal \\
\hline 102499 & $\mathrm{pMH} 12$ & IPR001138, IPR007219 & Fungal transcriptional regulatory protein, N-terminal; Transcription factor, fungi \\
\hline 62244 & $\mathrm{pMH13}$ & IPR001138, IPR007219 & Fungal transcriptional regulatory protein, N-terminal; Transcription factor, fungi \\
\hline 111742 & $\mathrm{pMH14}$ & IPR001138, & Fungal transcriptional regulatory protein, $\mathrm{N}$-terminal, \\
\hline 77513 & $\mathrm{pMH} 15$ & IPR007219 & Transcription factor, fungi \\
\hline 105263 & $\mathrm{pMH16}$ & IPR001138 & Fungal transcriptional regulatory protein, $\mathrm{N}$-terminal \\
\hline 112524 & $\mathrm{pMH17}$ & IPR001138, IPR007219 & Fungal transcriptional regulatory protein, N-terminal; Transcription factor, fungi \\
\hline 123668 & $\mathrm{pMH18}$ & IPR000182 & GCN5-related N-acetyltransferase \\
\hline 73792 & $\mathrm{pMH19}$ & IPR001138 & Fungal transcriptional regulatory protein, $\mathrm{N}$-terminal \\
\hline 80291 & $\mathrm{pMH} 20$ & IPR001138, IPRO007219 & Fungal transcriptional regulatory protein, N-terminal; Transcription factor, fungi \\
\hline 107858 & $\mathrm{pMH} 21$ & IPR001138 & Fungal transcriptional regulatory protein, $\mathrm{N}$-terminal \\
\hline 120120 & $\mathrm{pMH} 22$ & IPR000182 & GCN5-related N-acetyltransferase \\
\hline 47317 & $\mathrm{pMH} 24$ & IPR001138, IPR007219 & Fungal transcriptional regulatory protein, N-terminal; Transcription factor, fungi \\
\hline 74765 & $\mathrm{pMH} 25$ & IPR001487, IPR000210 & Bromodomain; BTB/POZ-like \\
\hline 76677 & $\mathrm{pMH} 26$ & IPR001138, IPR007219 & Fungal transcriptional regulatory protein, N-terminal; Transcription factor, fungi \\
\hline 55422 & $\mathrm{pMH} 27$ & IPR011009 & Protein kinase-like domain \\
\hline 121130 & $\mathrm{pMH} 28$ & IPR001138 & Fungal transcriptional regulatory protein, $\mathrm{N}$-terminal \\
\hline 122523 & $\mathrm{pMH} 29$ & IPR001138 & Fungal transcriptional regulatory protein, $\mathrm{N}$-terminal \\
\hline 123019 & $\mathrm{pMH} 30$ & IPR000719 & Protein kinase, catalytic domain \\
\hline 54703 & $\mathrm{pMH} 32$ & IPR007087 & Zinc finger, $\mathrm{C} 2 \mathrm{H} 2$-type \\
\hline 56077 & $\mathrm{pMH} 33$ & IPR001138 & Fungal transcriptional regulatory protein, $\mathrm{N}$-terminal \\
\hline 60215 & pMH34 & IPR001138 & Fungal transcriptional regulatory protein, $\mathrm{N}$-terminal \\
\hline 66966 & pMH35 & IPR001680 & WD40 repeat \\
\hline 64608 & pMH36 & IPR001680 & WD40 repeat \\
\hline 81972 & $\mathrm{pMH} 37$ & IPR001251 & Cellular retinaldehyde-binding/triple function, C-terminal \\
\hline
\end{tabular}




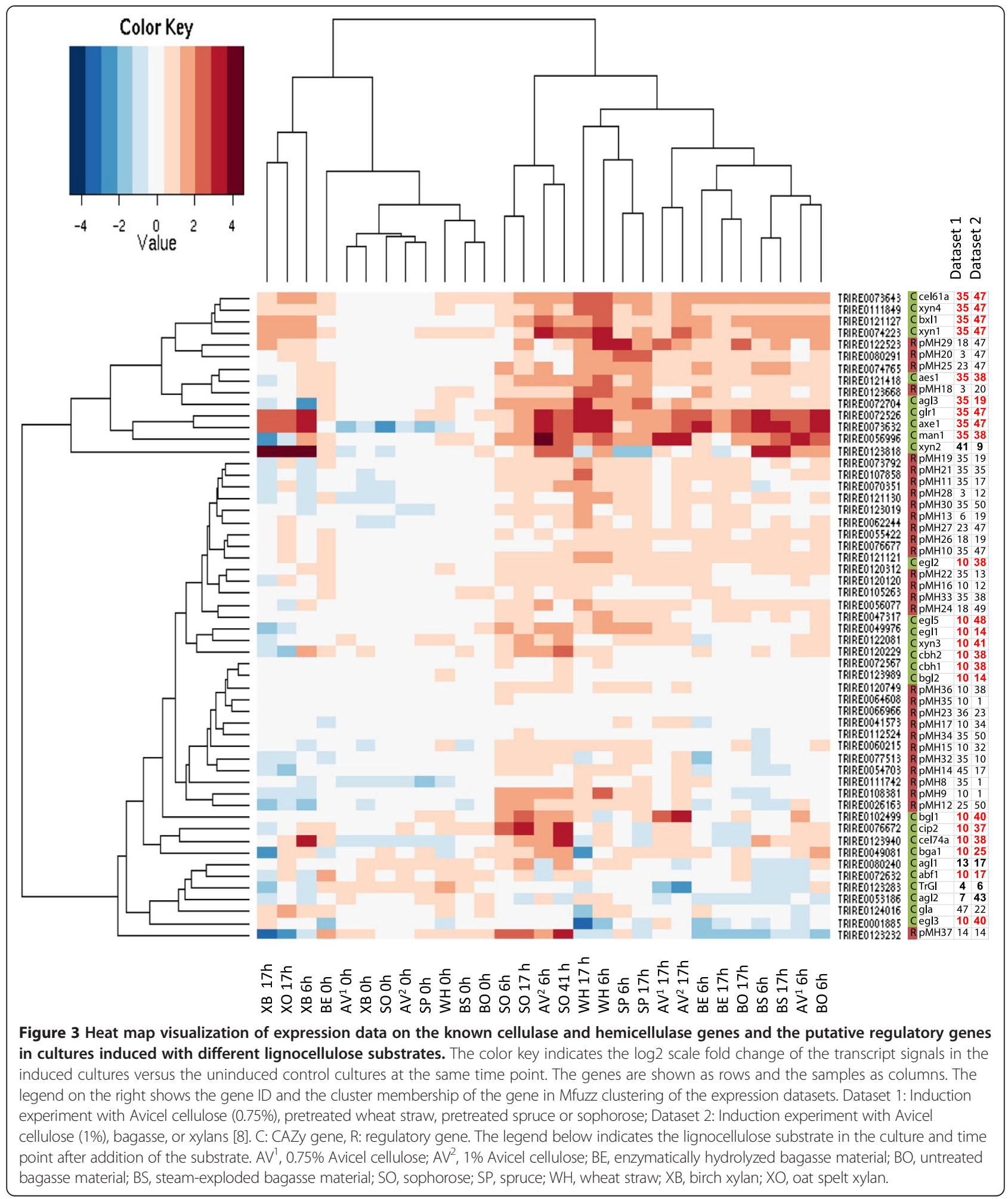

genes in the cellulase-enriched cluster (cluster 10). This group includes genes induced mainly by sophorose, Avicel cellulose, wheat or spruce, but not with bagasse material, and genes hardly induced at all. Detailed transcriptional data of the genes is presented in Additional file 1.
Primary screening of the effects of the candidate regulatory genes on the cellulase and xylanase production of $T$. reesei

In order to investigate the effects of the putative regulatory genes chosen from the data, T. reesei QM9414 
strains overexpressing the genes were constructed. The genes were cloned to an expression vector under the $A$. nidulans gpdA promoter and the expression plasmids were transformed to QM9414. A $\beta$-glucan plate assay was used for preliminary evaluation of enzyme production by the transformants and for selection of representative clones from the transformation for further analysis. The recombinant strains were cultivated in shake flasks on lactose containing rich medium to analyze the effect of the genetic modification on growth and protein production. Produced cellulase and xylanase activities (Figure 4) were measured throughout the cultivation. The growth of the strain transformed with the construct pMH12 was clearly defective as compared to the parental strain and to other recombinant strains, and was therefore omitted from further studies. The enzyme activity produced during the cultivation of the recombinant strains as compared to the activity produced in the cultures of the parental strain is summarized in Figure 4. Detailed information on production of the enzymatic activities during the time course of cultivation is shown in Additional file 2.

The strains overexpressing genes 77513, 74765, 80291, 66966, 123668, 64608 and 122523 (constructs pMH15, pMH25, pMH20, pMH35, pMH18, pMH36 and pMH29) produced cellulase and/or xylanase activity over 1.5 -fold as compared to the parental strain in the shake flask cultures. The integrity of these seven strains and overexpression of the genes were confirmed by southern and northern blot analysis, respectively (Additional files 3 and 4). Most of the modified strains tested had the overexpression construct integrated as a single copy. The strain overexpressing the construct pMH35 had one to two copies according to the Southern hybridization. For the construct pMH15, both a single-copy and a double-copy transformant were analyzed (Figures 5 and 6). Northern analysis showed 1.4- to 23.6-fold overexpression of the gene for the strains analyzed (Additional file 4), except for gene 123668 (pMH18), which was expressed at a low level both in the overexpression strain and in the parental strain and therefore was not quantified. In addition, a number of the recombinant strains (transformed with constructs pMH8, pMH13, pMH21, pMH22, pMH24, pMH26 and pMH37) produced clearly less enzymatic activity than the parental strain. These genes were omitted from further studies.

Overexpression of gene 77513 (construct pMH15) had the most consistent and statistically significant (t-test; $P<0.05)$ positive effect on both cellulase and xylanase production by $T$. reesei. The strain produced in the initial screening 3- to 4-fold cellobiohydrolase 1 (CBHI) activity, 2 - to 2.5-fold endoglucanase 1 (EGI) activity and 2- to 3fold combined activity as measured against the 4methylumbelliferyl- $\beta$-D-lactoside (MUL) substrate (Figure 4).
The strain also produced 2- to 3-fold more xylanase activity as measured against the parental strain.

The strain overexpressing gene 80291 (construct pMH20) produced 2.5-times more CBHI activity, 2times more EGI activity and 2.5-times more total activity against the MUL substrate. However, the xylanase activity was only slightly improved in this recombinant strain (less than 1.5-fold) as compared to the parental strain. The change in the production levels by pMH20 overexpression was statistically significant (t-test; $P<0.05$ ).

The overexpression of gene 74765 (construct pMH25) produced the largest amount of cellulase activity as measured volumetrically against the substrate MUL, as compared to the other recombinant strains and to the parental strain (almost 3.5-times more than the parental strain). Production of xylanase activity was also increased more than 1.5 times in the recombinant strain. However, T. reesei EGI (CEL7B) has been shown to have activity against xylans as well and thus the increase in xylanase activity could be partly due to the increase in EGI production [33].

\section{Quantitative PCR of cellulase and hemicellulase genes}

Based on the preliminary enzyme activity measurements, strains overexpressing genes 77513, 80291 and 74765 (constructs pMH15, pMH20 and pMH25) were selected for further studies. For clarity, the recombinant strains will be referred to by the construct names. A quantitative PCR analysis of axe1, bxl1, xyn1, xyn2, xyn3, cbh1, cbh2, egl1, bgl1 and $x y r 1$ was carried out. The results are shown as a fold change of the signals as compared to the parental strain QM9414 (Figure 7). For all the strains, the expression of $c b h 1, \operatorname{cbh} 2$ and egl1 was improved as compared to the parental strain, although for pMH20 and pMH25 the effect was more moderate and was detected for pMH20 only at the 3-day time point. The expression of the major $\beta$-glucosidase gene $b g l 1$ was clearly improved by the pMH15 and pMH25 constructs but not by pMH20. Similarly, the expression of the three xylanase genes was improved by pMH15 and pMH25. Regarding xylanase gene expression, the overexpression of gene 77513 (pMH15) seemed to have most effect on $x y n 3$, whereas the two other candidate regulatory genes were more specific to $x y n 1$ (only xylanase gene with improved expression by pMH20). Particularly, overexpression of gene 74765 (pMH25) had a major effect on the transcription of $x y n 1$. The expression of $b x l 1$ was moderately improved with pMH15 and pMH25. The clearest increase in axe1 expression was seen with pMH25. The expression of $x y r 1$, which encodes the major regulator of cellulase and hemicellulase genes, was higher in pMH15 than in the parental strain but was not affected in the other two strains. 


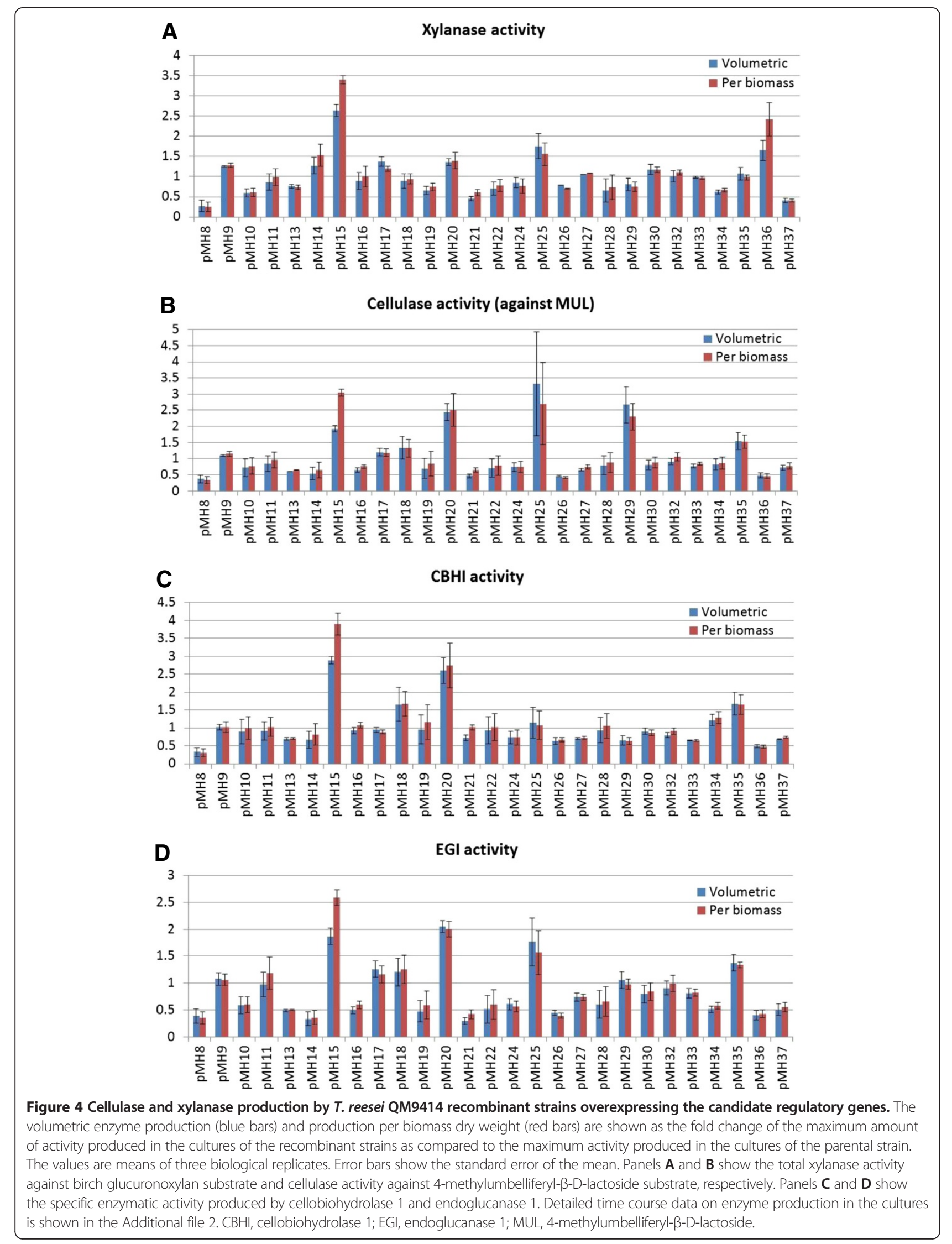




\section{A Cellulase activity (against MUL)}



C

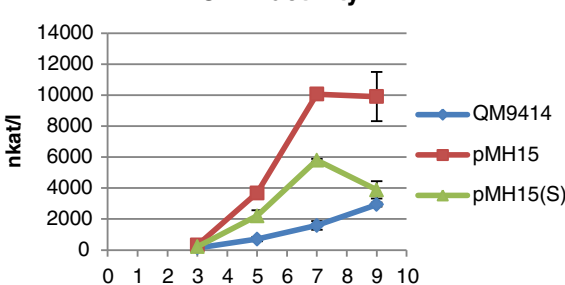

E

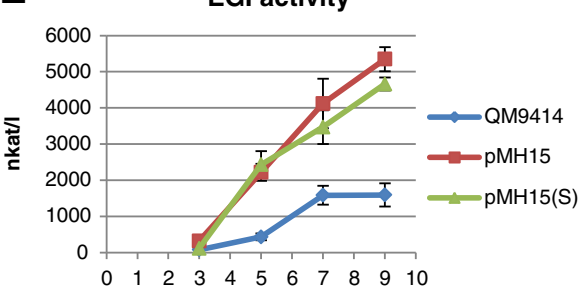

B Cellulase activity (against MUL)

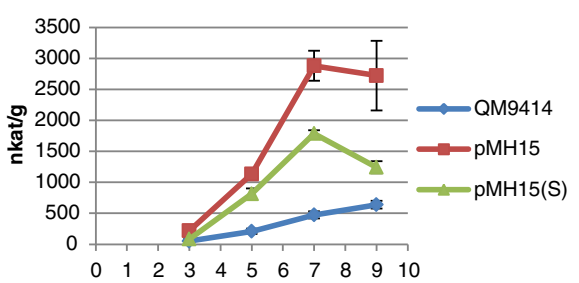

D

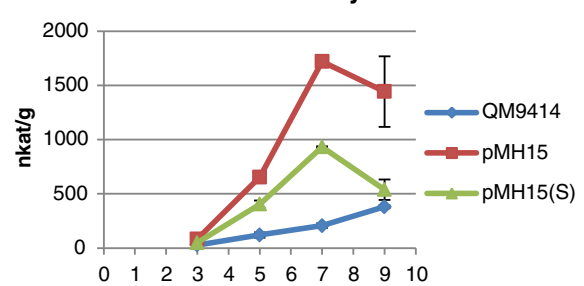

$\mathbf{F}$

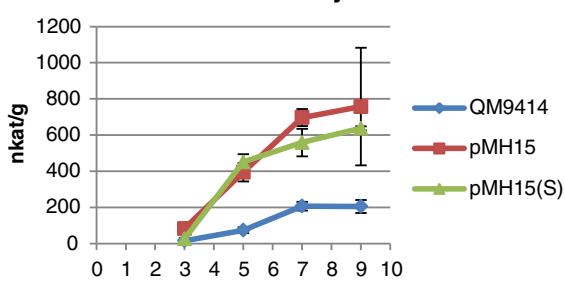

Figure 5 Production of cellulase activity by two different transformants overexpressing gene 77513. Transformants harboring the overexpression cassette as a single-copy (pMH15(S)) or as a double-copy (pMH15) were cultivated in shake flasks with lactose as a carbon source. Enzyme activity was measured at four different time points (3, 5, 7 and 9 days). The values are means of three biological replicates. Error bars show the standard error of the mean. Panels $\mathbf{A}$ and $\mathbf{B}$ show the volumetric and production per biomass dry weight of total cellulase activity against MUL substrate, respectively. Panels $\mathbf{C}-\mathbf{F}$ show the specific enzymatic activity produced by $\mathrm{CBH}$ and EGl. CBHI, cellobiohydrolase 1; EGl, endoglucanase 1; MUL, 4-methylumbelliferyl- $\beta$-D-lactoside.

\section{Overexpression and deletion of gene 77513 , designated as ace3}

Based on the quantitative PCR and enzyme production results of the recombinant strain overexpressing the construct pMH15, gene 77513 was selected for more detailed studies. A recombinant strain was constructed from which gene 77513 was deleted (designated Del77513). We also analyzed enzyme production by strains having both one (pMH15(S)) or two (pMH15) copies of the overexpression cassette and in the 77513 deletion strain (all the constructs were confirmed by Southern and Northern analyses, Additional files 3 and 4). Both overexpression
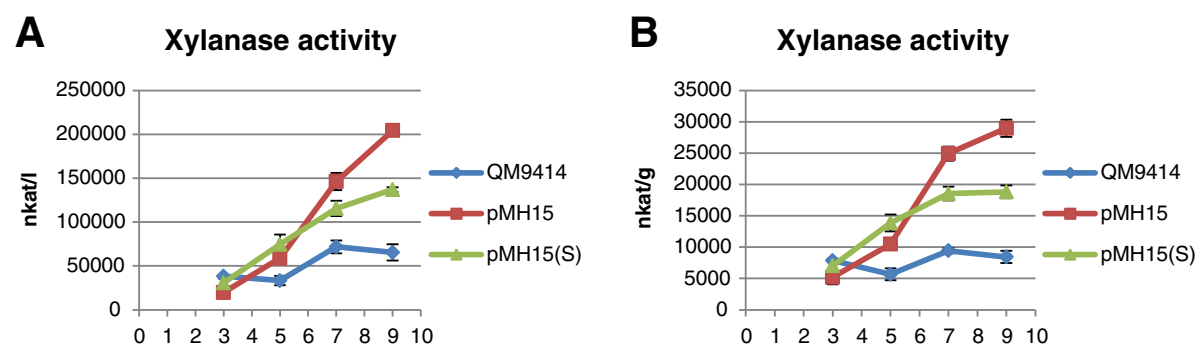

Figure 6 Production of xylanase activity by two different transformants overexpressing gene 77513. Transformants harboring the overexpression cassette as a single-copy (pMH15(S)) or as a double-copy (pMH15) were cultivated in shake flasks with lactose as a carbon source. Xylanase activity was measured at four different time points (3, 5,7 and 9 days). The values are means of three biological replicates. Error bars show the standard error of the mean. Panels $\mathbf{A}$ and $\mathbf{B}$ show the volumetric and production per biomass dry weight of xylanase activity, respectively. 




strains were cultivated in parallel with the deletion strain and the parental strains. Produced cellulase activity against the MUL substrate and xylanase activity were measured throughout the cultivation.

Both overexpression strains produced significantly (t-test; $P<0.05)$ more total MUL activity, CBHI, EGI and xylanase activity as compared to the parental strain (Figures 5 and 6). The improvement in cellulase and xylanase production was higher in the double-copy strain than in the single-copy strain, indicating that the possible double-integration of the expression cassette also amplified the positive effect of the overexpressed gene to cellulase and xylanase production. When gene 77513 was deleted, the production of total cellulase activity against the MUL substrate was abolished completely (Figure 8). Interestingly, production of xylanase activity decreased to approximately half that of the parental strain (most significant decrease at day 7), indicating that gene 77513 is not essential for the production of xylanase activity but does modulate it (Figure 8).

A quantitative PCR analysis of axe1, bxl1, xyn1, xyn2, $x y n 3$, cbh1, cbh2, egl1, bgl1 and $x y r 1$ was carried out for samples collected from the cultivation of strains PMH15, pMH15(S) and Del77513. Due to the different parental strains of the overexpression strains and the deletion strain, the results are shown normalized with the signal of sar1 (Figures 9 and 10). The expression of $c b h 1, c b h 2$, egl1, bgl1, xyn1, xyn2, xyn3 and xyr1 was higher in the overexpression strains as compared to the parental strain. In accordance with the enzymatic activity measurements, the increase in the gene expression was higher in the double-copy strain than in the single-copy strain. The expression of $b x l 1$ was improved only in the double-copy strain.

Expression of $c b h 1, c b h 2$, egl1, axe 1 and $x y n 3$ was almost undetectable in the deletion strain as compared to the parental strain. The expression of $b x l 1, x y n 1, x y n 2$, bgll and xyrl was also lower as compared to the parental strain. In the light of the enzymatic activity and quantitative PCR results for the two strains overexpressing gene 77513 and for the strain with the gene deleted, this gene was named activator of cellulase expression 3 (ace3).

\section{Discussion}

The double-lock gene regulation mechanism, in which a master transcription factor regulates an additional transacting regulatory factor gene together with its actual target genes, is well-documented in filamentous fungi. In particular, carbon catabolite repression has been reported to be mediated by such a mechanism. In the model organism $A$. nidulans, the carbon catabolite repressor CREA regulates the ethanol utilization genes by repressing both the positively acting regulatory gene alcR and its target, alcA [34]. CREA also regulates lignocellulolytic genes by repressing the major activator $(x \ln R)$ as well as many of its target genes, for example, $x \ln D$ and $x \ln B$ [35]. Similarly, the major regulator of cellulolytic and xylanolytic genes in T. reesei ( $x y r 1$, a homologue of $x \ln R$ ) is repressed by the carbon catabolite repressor CRE1 together with many xyr1 target genes [18,36].

In this study, we utilized the principle of the doublelock mechanism to find new regulators of cellulase and 


\section{A Cellulase activity (against MUL)}
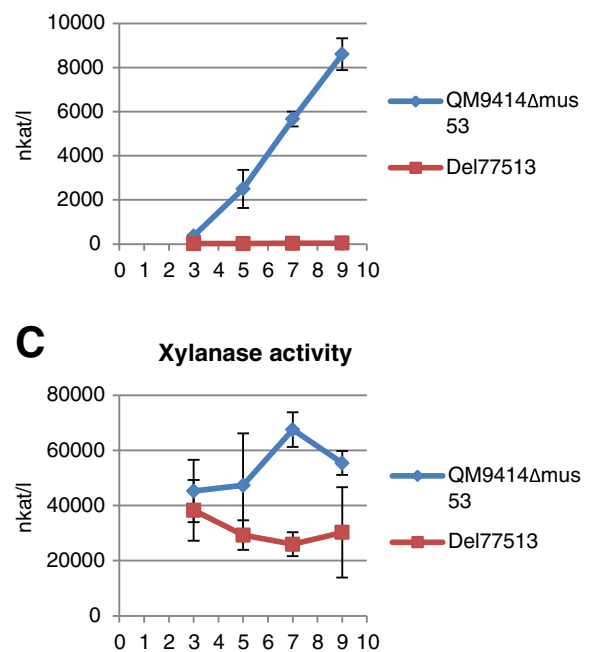

B Cellulase activity (against MUL)

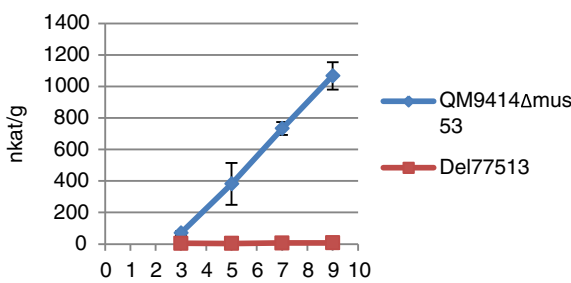

Dylanase activity

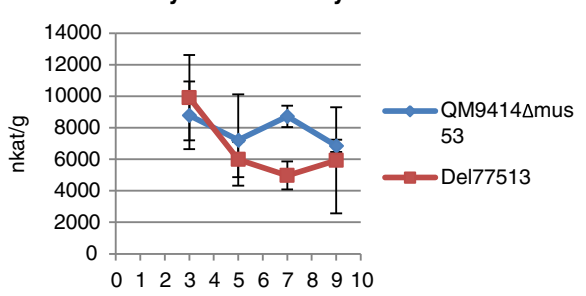

Figure 8 Production of cellulase and xylanase activity by the 77513 deletion strain. Del77513 was cultivated in shake flasks in lactose containing medium in parallel with the parental strain QM9414 $\Delta$ mus53. Enzyme activity was measured at four different time points (3, 5, 7 and 9 days). The values are means of three biological replicates. Error bars show the standard error of the mean. Panels $\mathbf{A}$ and $\mathbf{B}$ show the volumetric and production per biomass dry weight of total cellulase activity against MUL substrate, respectively. Panels $\mathbf{C}$ and $\mathbf{D}$ show the volumetric and production per biomass dry weight of xylanase activity, respectively. MUL, 4-methylumbelliferyl- $\beta$-D-lactoside.

hemicellulase genes, presuming that these regulators would be regulated in a similar manner as their target genes. We analyzed transcriptome data from $T$. reesei cultures induced with different lignocellulose-derived substances to search for candidate regulatory genes. This led to identification of 89 candidate genes that were co-induced with many of the known cellulase or hemicellulase genes in the presence of different lignocellulosederived materials. We selected 28 genes for overexpression screening by taking into account supporting evidence from other genome-wide datasets, such as transcriptome and proteome analysis of chemostat cultures with different protein production rates [14], as well as location of the genes in the genome.

Clustering of the biosynthesis genes for fungal secondary metabolites together with their regulatory genes in the genome, as well as the regulatory cascades including chromatin-mediated regulation of the genomic regions, is relatively well-characterized in fungi (for a review, see [37]). Recent studies have indicated that chromatin level regulation also takes place in the regulation of CAZy genes of $T$. reesei. The putative methyltransferase LAE1, a homologue of LaeA functioning in chromatin level regulation of secondary metabolism in Aspergilli, has been shown to be involved in controlling cellulase gene expression in $T$. reesei, although the actual mechanism is not fully understood [38]. Furthermore, genes with significant up- or down-regulation during conidiation [39] as well as genes whose expression levels correlate with the specific production rate of extracellular proteins [14] have been shown to be non-randomly distributed in the T. reesei genome. Genes encoding, for example, secondary metabolism proteins, CAZys, putative transporters and putative transcription factors have been identified from such genomic clusters. In addition, the protein families of these regulators and the protein families of CAZys and secondary metabolism-related enzymes have recently expanded in the evolution of filamentous fungi, (Pezizomycotina) [40]. Thus, positioning of the regulatory genes in the close vicinity of their target genes (or other genes involved in the same process) may not be limited to the secondary metabolism genes, but could involve the genes active in lignocellulose degradation as well.

The transcriptome data on the cultures induced with different lignocellulosic material showed genomic regions that are co-regulated in an inducer-specific manner. Of the genes that were co-expressed with the major cellulase and hemicellulase genes according to the Mfuzz clustering, 22.7\% were located in enriched genomic regions ( $\geq$ three genes within a window of nine genes, with a maximal distance of five genes). Of these, 9.1\% (32 genes) were located next to each other in patches of three or more genes and were tightly coregulated.

In addition to the known regulatory gene for hemicellulase and cellulase genes, xyrl, nine candidate regulatory genes were located in these tightly co-regulated regions or within close vicinity (Figure 2). Interestingly, four of the genes were located next to a putative sugar 


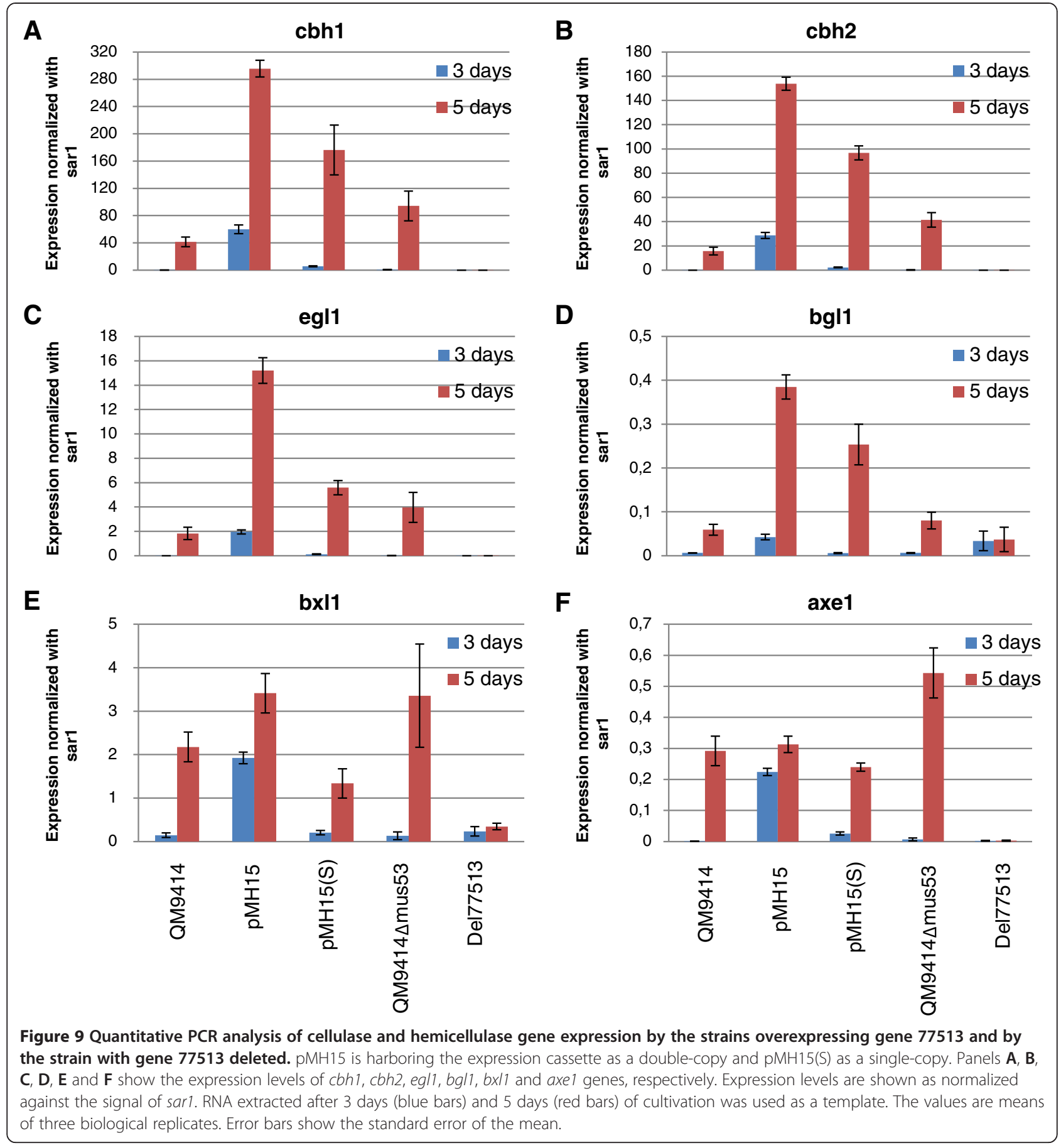

transporter and/or a $\beta$-glucosidase gene. In addition to the release of glucose from cellobiose by extracellular $\beta$-glucosidases and transport of sugars into the cells, the sugar transporters and $\beta$-glucosidases may have a special role in the onset of the CAZy gene induction. Sugar units derived from the complex carbon source may be transported inside the cells and further modified by intracellular $\beta$-glucosidases to form an inducing compound, such as sophorose via a transglycosylation reaction. The gene cel3e, located next to gene 105263 (pMH16), encodes a predicted extracellular $\beta$-glucosidase. By contrast, cel3d and cel1b, located next to genes 121121 (pMH10) and 77513/ace3 (pMH15), respectively, are predicted to encode intracellular enzymes. Interestingly, the sugar transporter genes located next to genes ace 3 and 26163 have recently been suggested to be involved in lactose uptake and cellulase production in lactosecontaining media [41,42]. 


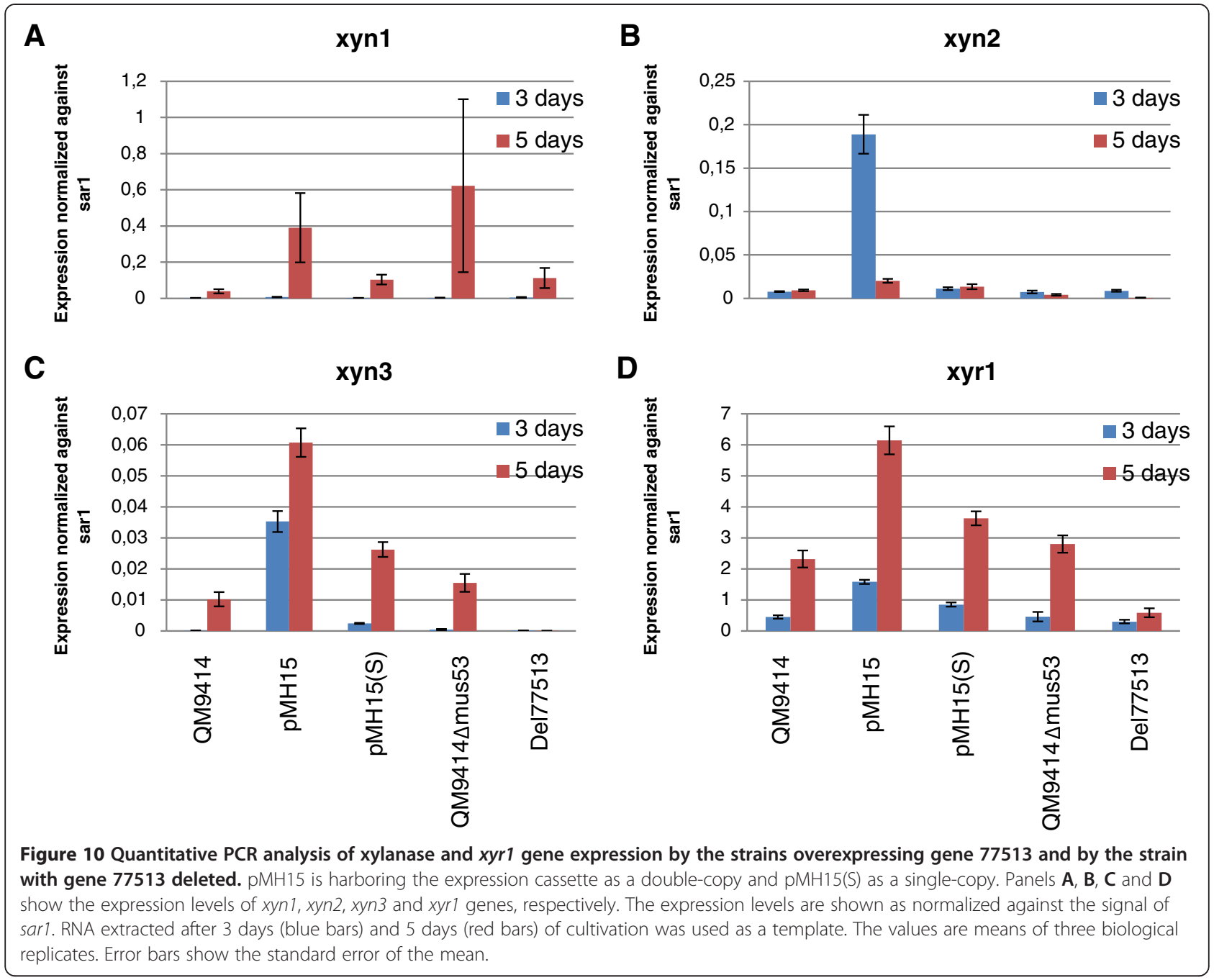

Co-location of a putative regulatory gene with a $\beta$ glucosidase gene and a transporter gene is not a unique feature of the $T$. reesei genome. For example, the homologues of 77513/ace3 (pMH15) in A. fumigatus (AFUA 016410) and in A. clavatus (ACLA_01970) are accompanied by a candidate $\beta$-glucosidase gene (AFUA_1G16400/ ACLA_01980) and a candidate hexose transporter gene (AFUA_1G16390/ACLA_019190) next to it in the genome. Similarly, the homologues of gene 121121 (pMH10) in A. fumigatus (AFUA_7G00210) and in A. nidulans (ANIA_02615) are located next to a candidate hexose transporter gene (AFUA_7G00220/ANIA_02614), a candidate major facilitator superfamily multidrug transporter gene (AFUA_7G2613/ANIA_02614), and a $\beta$-glucosidase gene (AFUA_7G00240/ANIA_026142) [43].

In a recent study, it was suggested that, in $N$. crassa, the cellulase/hemicellulase regulator CLR-1 would promote the expression of cellodextrin transporters and $\beta$ glucosidase genes as well as a second regulatory gene, clr-2, which in turn activates cellulase genes [25]. In $N$. crassa, clr-2 is essential for cellulase production in the presence of Avicel cellulose [25]. In $T$. reesei, the homologue of $c l r-2$, gene 26163 (construct pMH9), is located next to a co-regulated sugar transporter gene that has recently been described as a lactose permease essential for the induction of $c b h 1$ and $c b h 2$ [42]. Overexpression of gene 26163 alone resulted only in a minute enhancement in production of cellulase and xylanase activity. However, no close homologue for $c l r-1$ can be identified from $T$. reesei, suggesting an important difference in the activation mechanisms of $c l r-2 / 26163$ and/or the accompanying transporter genes in $N$. crassa and in T. reesei.

Overexpression of genes 105263 (pMH16) and 121121 (pMH10) did not have a significant effect on protein production under the conditions studied. However, overexpression of ace3, which is located next to a coregulated $\beta$-glucosidase gene (cel1b) and a candidate sugar transporter gene in its original locus, resulted in a significantly increased production of cellulase and xylanase 
activity as compared to the parental strain. Deletion of the gene was detrimental to the production of cellulase activity and decreased the production of xylanase activity. Quantitative PCR analysis of transcript levels of cellulase and xylanase genes supported the enzymatic activity measurements. Therefore, ace3 can be considered to code for a novel master regulator of cellulase expression and a modulator of xylan degrading enzyme expression. Thus its role appears to be different from that of XYR1/XlnR, which has a major role in both xylan and cellulose degradation [18,44]. Interestingly, the Mfuzz clustering of ace 3 reflects the quantitative PCR results to some extent. The gene clustered together with egl1, cbh1, cbh2, bgl1 and xyn3, which were most affected by ace 3 modifications, whereas axe1, bxl1, xyn1 and xyn2 are in different clusters.

Transcription of xyr1 was increased in the strains overexpressing ace 3 and decreased in the deletion strain, indicating that the effects on the target genes observed could be at least partly mediated via xyr1. However, the deletion of ace 3 did not totally abolish xyr 1 transcription. Therefore, the absence of XYR1 is not an explanation for the total lack of cellulase activity and gene expression exhibited by the deletion strain.

\section{Conclusions}

Combining genome-wide data on cultures with different protein production properties is a useful method for identifying novel regulatory genes relevant for cellulase and xylanase production in T. reesei. Altogether, overexpression of seven of the candidate regulatory genes resulted in improved ( $>1.5$ fold) production of cellulase and/or xylanase activity as compared to the parental strain. Further studies are required to confirm the role of most of these genes in cellulase and hemicellulase gene regulation and to elucidate the actual regulatory mechanisms. However, our data show a positive effect of cellulase and/or xylanase gene expression for three of the candidate regulatory genes. The deletion of one of these genes, ace3, totally abolished cellulase expression and reduced xylan degrading enzyme expression, thus identifying it as a novel master regulator of lignocellulose degradation. Furthermore, our data reveal genomic regions enriched in co-regulated CAZy genes and candidate regulatory genes, therefore supporting the hypothesis that chromatin-level regional regulation plays a role, at least in part, in the expression of CAZy genes in $T$. reesei.

\section{Methods}

Strains, media and culture conditions

Escherichia coli DH5 $\alpha$ (fhuA2 $\triangle$ (argF-lacZ)U169 phoA glnV44 $\Phi 80 \Delta$ (lacZ)M15 gyrA96 recA1 relA1 endA1 thi$1 \mathrm{hsdR} 17)$ was used for propagation of the plasmids. $T$. reesei Rut-C30 (ATCC 56765, VTT-D-86271), QM6a (ATCC13631, VTT-D-071262 T) and QM9414 (ATCC 26921, VTT-D-74075) were obtained from VTT Culture Collection (Espoo, Finland). Spore suspensions were prepared by cultivating the fungus on potato-dextrose plates (BD, Sparks, Maryland, USA ) for 5 days, after which the spores were harvested, suspended in a buffer containing $0.8 \% \mathrm{NaCl}, 0.025 \%$ Tween 20 and $20 \%$ glycerol, filtered through cotton, and stored at $-80^{\circ} \mathrm{C}$. For DNA isolation, the fungus was grown in a medium containing $0.2 \%$ pro-

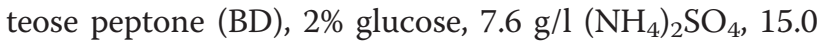
$\mathrm{g} / \mathrm{KH}_{2} \mathrm{PO}_{4}, 2.4 \mathrm{mM} \mathrm{MgSO} 4.7 \mathrm{H}_{2} \mathrm{O}, 4.1 \mathrm{mM} \mathrm{CaCI} \cdot \mathrm{H}_{2} \mathrm{O}$, $3.7 \mathrm{mg} / \mathrm{l} \mathrm{CoCI}_{2}, 5 \mathrm{mg} / \mathrm{FeSO}_{4} .7 \mathrm{H}_{2} \mathrm{O}, 1.4 \mathrm{mg} / \mathrm{l} \mathrm{ZnSO}_{4}$. $7 \mathrm{H}_{2} \mathrm{O}$ and $1.6 \mathrm{mg} / \mathrm{l} \mathrm{MnSO}_{4} \cdot 7 \mathrm{H}_{2} \mathrm{O}, \mathrm{pH} 4.8$.

\section{Transcriptional profiling data}

Transcriptional profiling data used in the study have been described elsewhere [8]. In short, pre-cultures of $T$. reesei Rut-C30 were first cultivated on a minimal medium containing sorbitol as a carbon source. Cellulase and hemicellulase gene expression was induced by addition of different lignocellulose material, purified lignocellulose-derived polymers or specific disaccharides (Cultivation set 1: addition of Avicel cellulose, pretreated wheat straw, pretreated spruce or sophorose; Cultivation set 2: addition of Avicel cellulose, birch xylan, oat spelt xylan, or differentially pretreated bagasse). Wheat straw and spruce were pretreated using steam explosion. Three different pretreatment methods were applied to bagasse, including grinding of the untreated bagasse material, steam explosion, or steam explosion followed by enzymatic treatment. Enzymatic pretreatment was done with a commercial cellulase and hemicellulase mixture followed by a protease treatment. Samples for transcriptional profiling were collected at different time points of induction $(0,6$ or $17 \mathrm{~h})$.

Custom-made microarray slides from RocheNimbleGen were used for transcriptional profiling. Sample preparation, hybridization onto microarray slides and collection of raw data was carried out as instructed by Roche. The microarray data were analyzed using the $\mathrm{R}$ package Oligo for preprocessing of the data and the package Limma for identifying differentially expressed genes [28,32]. In the analysis of the differentially expressed genes, the signals in the samples of the induced cultures were compared to the ones in the uninduced control cultures at the corresponding time point as described in [8]. Four biological replicates of each condition and time point were analyzed. The cut-off used for statistical significance was $P<0.01$, and an additional cut-off for the $\log 2$ scale fold change was set as 0.4 . In addition, the expression array datasets were clustered using the R package Mfuzz [29]. Co-expressed genomic clusters were determined by enrichment of Mfuzz cluster members in the genomic regions. Three or more 
gene members of the expression cluster within a window of nine neighboring genes and with the maximal distance of five genes were considered as a genomic region enriched with co-regulated genes. In addition, genomic regions with multiple adjacent genes belonging to the same expression cluster were searched for.

The expression of the selected candidate regulatory genes was compared to the transcriptome and proteome data described in [14].

\section{Construction of $T$. reesei strains overexpressing candidate regulatory genes}

The regulatory genes were amplified by PCR using Gateway compatible primers (Table 3) and the genomic DNA of T. reesei QM6a as a template. For the majority of the genes, the open reading frame (ORF) predictions used were as in the genome version 2.0 [45] with the following exceptions: the primers for genes 26163 and 64608 and the N-terminal primer for gene 47317 were designed according to the ORF prediction in archived genome version 1.0 [46], and the ORF prediction for gene 64608 was modified by taking into account expressed sequence tag sequence data. In order to construct the plasmid vectors for overexpression of the genes in T. reesei, the PCR fragments were inserted in the expression vector pMS204 using the Gateway recombination system (One-Tube protocol) according to the manufacturer's instructions (Invitrogen, Carlsbad, California, USA). The expression vector contains the hygromycin resistance gene ( $\mathrm{ZP}_{-}$ 12918108) under the A. nidulans gpdA promoter [47] and $\operatorname{trp} C$ terminator [48], as well as an additional copy of the gpdA promoter and $\operatorname{trp} C$ terminator for expression of the gene of interest (the vector map is illustrated in Additional file 5). The plasmids were linearized using HindIII, PciI or SpeI enzyme (New England BioLabs, Ipswich, Massachusetts, USA) and transformed to T. reesei QM9414 by polyethylene glycol-mediated protoplast transformation [49]. The transformants were selected for hygromycin resistance on plates containing $150 \mu \mathrm{g} \mathrm{ml}^{-1}$ of hygromycin B (Calbiochem, San Diego, California, USA). Stable transformants were obtained by streaking on plates containing $125 \mu \mathrm{g} \mathrm{ml}^{-1}$ of hygromycin B for two successive rounds, after which single colonies were obtained by plating dilutions of spore suspensions. Integration was verified by PCR with one primer binding the gpdA promoter and one binding the ORF of the overexpressed gene (the primers used are listed in Table 4). The cellulase production levels of transformants from each construct were assayed on $\beta$-glucan plates (see below). Southern blot analysis was carried out for additional confirmation of the transformants showing improved protein production as compared to the parental strain. Genomic DNA was isolated using an Easy-DNA Kit (Invitrogen) according to manufacturer's instructions. Southern blotting and hybridization on nitrocellulose filters (Hybond N, GE Healthcare, Little Chalfont, UK) were carried out according to standard procedures [50]. Probe fragments were PCR-amplified from the genomic DNA. The signals were detected using a phosphorimager (Typhoon imager, GE Healthcare).

\section{Plate assay for $\beta$-glucan hydrolysis using Congo red staining}

For detection of enzymatic activity against the $\beta$-glucan produced by fungal colonies, spores were mixed with $50^{\circ} \mathrm{C}$ top agar containing $0.1 \% \quad \beta$-glucan (Megazyme, Bray, Wicklow, Ireland), $2 \%$ lactose (Fagron, Rotterdam, the Netherlands), $0.05 \%$ proteose peptone (BD), $7.6 \mathrm{~g} / \mathrm{l}\left(\mathrm{NH}_{4}\right)$ ${ }_{2} \mathrm{SO}_{4}, 15.0 \mathrm{~g} / \mathrm{KH}_{2} \mathrm{PO}_{4}, 2.4 \mathrm{mM} \mathrm{MgSO}{ }_{4} .7 \mathrm{H}_{2} 0,4.1 \mathrm{mM}$ $\mathrm{CaCl}_{2} \cdot \mathrm{H}_{2} \mathrm{O}, 3.7 \mathrm{mg} / \mathrm{l} \mathrm{CoCI} 2,5 \mathrm{mg} / \mathrm{FeSO}_{4} .7 \mathrm{H}_{2} \mathrm{O}, 1.4 \mathrm{mg} / \mathrm{l}$ $\mathrm{ZnSO}_{4} .7 \mathrm{H}_{2} \mathrm{O}, 1.6 \mathrm{mg} / \mathrm{l} \mathrm{MnSO}_{4} .7 \mathrm{H}_{2} \mathrm{O}, 0.1 \%$ Triton TX100 (Fluka, St Louis, Missouri, USA) and 3\% agar Noble (BD), $\mathrm{pH} 5.5$, and plated on solid medium (composition of the medium was the same as that of the top agar except that $\beta$-glucan was omitted and the concentration of agar Noble was $1.8 \%(\mathrm{w} / \mathrm{v}))$. After 4 days of cultivation at $28^{\circ} \mathrm{C}$, the plates were rinsed with $0.9 \% \mathrm{NaCl}$, submerged in $0.1 \%$ Congo red (Merck, Darmstadt, Germany) in 1 M Tris$\mathrm{HCl}(\mathrm{pH}$ 9.5), and incubated for $30 \mathrm{~min}$ with shaking at $100 \mathrm{rpm}$. After the incubation, the plates were washed with $0.9 \%(\mathrm{w} / \mathrm{v}) \mathrm{NaCl}$, and the diameter of the colonies and the halo around them were measured. The size of the halo compared to the colony size was calculated and compared to the corresponding size of the parental strain QM9414.

\section{Construction of a deletion strain}

The deletion cassette for the deletion of gene 77513 was constructed by Golden Gate cloning [51]. The construct contained the hygromycin resistance cassette (gpdA promoter, hygromycin resistance gene, trpC terminator) flanked by $1.523 \mathrm{~kb}$ and $1.024 \mathrm{~kb}$ fragments from the $5^{\prime}$ and $3^{\prime}$ sides of the ORF of 77513, respectively. The $5^{\prime}$ flanking region fragment was amplified by PCR with oligos 5'-GCGCGGTCTCCGGGTGGCGAGGTGGGAGA AGGGGA-3' and 5'-GCGCGGTCTCGCATGGGAAG ACGAGGTCGGTGTTG-3'. The 3 '-flanking region was amplified by PCR with oligos 5'-GCGCGGTCTCCGA GAAAGCGGTCGGGGAAATGGCG-3' and 5'-GCGC GGTCTCGGCGGTTGCGTGGGCGTT GCTCGAT-3'. The fragments of the marker cassette and the flanks were first ligated to a pBsV2 vector [52] and subsequently cloned to a modified pBluescript vector (lacking the BsaI site). The deletion cassette was digested from the vector with PmeI enzyme and transformed to T. reesei QM9414 $\Delta$ mus53 strain (QM9414 strain from which gene 58509 had been deleted) with high targeted integration frequency. 
Table 3 Gateway compatible primers for the cloning of the putative regulatory genes

\begin{tabular}{|c|c|c|}
\hline Construct & 5'primer & 3'primer \\
\hline pMH8 & 5'GGGGACAAGTTTGTACAAAAAAGCAGGCTTGCGCATCATGGCGCTCTTTGTCTGCTTGG & 3'GGGGACCACTTTGTACAAGAAAGCTGGGTCCTATTGTTGCTGCCCGCCCCA \\
\hline $\mathrm{pMH9}$ & 5'GGGGACAAGTTTGTACAAAAAAGCAGGCTACATCATGTTCTACACATGTGG & 3'GGGGACCACTTTGTACAAGAAAGCTGGGTTTCACGACGGCGGTAGAGC \\
\hline $\mathrm{pMH10}$ & 5'GGGGACAAGTTTGTACAAAAAAGCAGGCTCGCACTAGAGCACAATGGAGAC & 3'GGGGACCACTTTGTACAAGAAAGCTGGGTGCTACTTCTGTATACACTTAATCAC \\
\hline $\mathrm{pMH11}$ & 5'GGGGACAAGTTTGTACAAAAAAGCAGGCTTGCGCATCATGGCCTCCAATGCCAAC & 3'GGGGACCACTITGTACAAGAAAGCTGGGTTTCATAATCAGACCAGCTCTTTC \\
\hline $\mathrm{pMH12}$ & 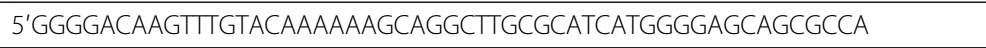 & $\begin{array}{l}\text { 3'GGGGACCACTTTGTACAAGAAAGCTGGGTTCTAGCCGTAAATCTATGTAGTTGA } \\
\end{array}$ \\
\hline $\mathrm{pMH13}$ & 5'GGGGACAAGTTTGTACAAAAAAGCAGGCTTGCGCATCATGCCACGCCCAAAAGTCCACC & 3'GGGGACCACTTTGTACAAGAAAGCTGGGTATCAGAACCCAAACGCCCGCGG \\
\hline $\mathrm{pMH14}$ & 5'GGGGACAAGTTTGTACAAAAAAGCAGGCTTGCGCATCATGGCGTCCTCTTACGGCACTC & 3'GGGGACCACTTTGTACAAGAAAGCTGGGTGTTAGAATACTAAACTCTTCGC \\
\hline pMH15 & $\begin{array}{l}\text { 5'GGGGACAAGTTTGTACAAAAAAGCAGGCTTGCGCATCATGCTGCGCTACTCCCCCGTCT } \\
\end{array}$ & 3'GGGGACCACTTTGTACAAGAAAGCTGGGTTTTAGCCAACAACGGTAGTGGA \\
\hline pMH16 & 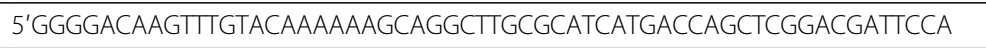 & 3'GGGGACCACTTTGTACAAGAAAGCTGGGTCTCAGGTGAAGGAGGGCGGTAT \\
\hline $\mathrm{pMH17}$ & 5'GGGGACAAGTTTGTACAAAAAAGCAGGCTTGCGCATCATGGCTGGATCGCCTGCTGCTG & 3'GGGGACCACTTTGTACAAGAAAGCTGGGTACACATTCATCCCTGCGCCCAG \\
\hline $\mathrm{pMH18}$ & $\begin{array}{l}\text { 5'GGGGACAAGTTTGTACAAAAAAGCAGGCTTGCGCATCATGCCTCTCGTTGTCGTCCCAG } \\
\end{array}$ & 3'GGGGACCACTTTGTACAAGAAAGCTGGGTCTTAATTGAGCAGCGGCTCGCG \\
\hline $\mathrm{pMH19}$ & 5'GGGGACAAGTTTGTACAAAAAAGCAGGCTTGCGCATCATGGATCTGCAATCCTTTGACA & 3'GGGGACCACTTTGTACAAGAAAGCTGGGTCCTACAGACGCTTTCCGAAAAAG \\
\hline $\mathrm{pMH} 20$ & 5'GGGGACAAGTTTGTACAAAAAAGCAGGCTTGCGCATCATGGGCCGGCAACCGAGACAAC & 3'GGGGACCACTTTGTACAAGAAAGCTGGGTATTATATAAACGGGGCATCAAT \\
\hline $\mathrm{pMH} 21$ & 5'GGGGACAAGTTTGTACAAAAAAGCAGGCTTGCGCATCATGGTTCGAGGCACCGGATC & 3'GGGGACCACTTTGTACAAGAAAGCTGGGTTCTAAGAAACATCTTCCGACCTGA \\
\hline $\mathrm{pMH} 22$ & 5'GGGGACAAGTTTGTACAAAAAAGCAGGCTTGCGCATCATGTCCCGCCAAATCTCC & 3'GGGGACCACTTTGTACAAGAAAGCTGGGTCTTACTCGGTGCTGATACTTCT \\
\hline $\mathrm{pMH} 24$ & 5'GGGGACAAGTTTGTACAAAAAAGCAGGCTTGCGCATCATGTCGTCAAACGCTTCACCG & 3'GGGGACCACTTTGTACAAGAAAGCTGGGTCCTAGCCCAAATGGCCCATATTG \\
\hline $\mathrm{pMH} 25$ &  & 3'GGGGACCACTTTGTACAAGAAAGCTGGGTCCTACTCGCCCTCTTCGCCTC \\
\hline $\mathrm{pMH} 26$ & 5'GGGGACAAGTTTGTACAAAAAAGCAGGCTTGCGCATCATGGCCGACACCCCGACTC & 3'GGGGACCACTITGTACAAGAAAGCTGGGTTITAGAAGCCCGCCTGCTCTGC \\
\hline $\mathrm{pMH} 27$ & 5'GGGGACAAGTTTGTACAAAAAAGCAGGCTTGCGCACAATGCCTCGCCGCGCCT & 3'GGGGACCACTTTGTACAAGAAAGCTGGGTTTCATTCATCGCCCCAGAACAA \\
\hline $\mathrm{pMH} 28$ & $\begin{array}{l}\text { 5'GGGGACAAGTTTGTACAAAAAAGCAGGCTTGCGCATCATGAACATGACGACAACGCT } \\
\end{array}$ & 3'GGGGACCACTTTGTACAAGAAAGCTGGGTTCTATCTATAACTTGGTATTITGC \\
\hline pMH29 & 5'GGGGACAAGTTTGTACAAAAAAGCAGGCTTGCGCATCATGGTAGCACATAGTCTACCCTCT & 3'GGGGACCACTTTGTACAAGAAAGCTGGGTCTCATATCGGCACCATGTCG \\
\hline $\mathrm{pMH} 30$ & 5'GGGGACAAGTTTGTACAAAAAAGCAGGCTTGCGCATCATGCTCATCAACAACCTCGATCC & 3'GGGGACCACTTTGTACAAGAAAGCTGGGTGTCAGACGAAACGCCGCCAG \\
\hline pMH32 &  & 3'GGGGACCACTITGTACAAGAAAGCTGGGTCTCACATACCCATAATCATTCCTC \\
\hline$\overline{\mathrm{pMH} 33}$ & 5'GGGGACAAGTTTGTACAAAAAAGCAGGCTTGCGCATCATGACATCAATAACGCATCCCTC & 3'GGGGACCACTTTGTACAAGAAAGCTGGGTTGCCTTCATCTCCTGGTGGAAT \\
\hline pMH34 & 5'GGGGACAAGTTTGTACAAAAAAGCAGGCTTGCGCATCATGTTCGGACAGTACTCACTCG & 3'GGGGACCACTTTGTACAAGAAAGCTGGGTATTACGACAATGGCAAGATCCT \\
\hline pMH35 & 5'GGGGACAAGTTTGTACAAAAAAGCAGGCTTGCGCATCATGGCCAAGAAGGCGCGTC & 3'GGGGACCACTITGTACAAGAAAGCTGGGTGCTAGGCGCCGTTGACGACTC \\
\hline pMH36 & 5'GGGGACAAGTTTGTACAAAAAAGCAGGCTTGCGCATCATGTCCAGATTCTGTCCGCT & 3'GGGGACCACTTTGTACAAGAAAGCTGGGTGCATCAATAGGCCGTATCAGAG \\
\hline pMH37 & 5'GGGGACAAGTTTGTACAAAAAAGCAGGCTTGCGCATCATGACGGCCGAGTACGAAG & 3'GGGGACCACTTTGTACAAGAAAGCTGGGTCTCGTTCATGCAGCAGCAG \\
\hline
\end{tabular}


Table 4 Primers for the PCR screening of the overexpression strains

\begin{tabular}{|c|c|}
\hline Primer & Sequence 5'- 3' \\
\hline pgpdA & GGCAGTAAGCGAAGGAGAATG \\
\hline pMH8R1 & ACACGGCTTCTTATATCTCGACC \\
\hline pMH9R3 & ATGGTCTCGATGTGGCTGCT \\
\hline pMH10R1 & CTGCGAGAGCAGCTAGGAGC \\
\hline pMH11R2 & CGTCGATTCGCGCTTGAACA \\
\hline $\mathrm{pMH} 12 \mathrm{R} 2$ & GATGCACGCCGCCATCGAGT \\
\hline pMH13R2 & TCGTTCTCCTCGTAGATTCAG \\
\hline pMH14R1 & GCTGGCTCTTCTCCCTCACAC \\
\hline pMH15R3 & TGAGTATAGCGGCTGACTTGTCG \\
\hline pMH16R3 & CTCGTTGACTTGCAGGCCTTG \\
\hline pMH17R1 & CTGAGGGCTGTAGACGCACTC \\
\hline pMH18R1 & TTACAGAGGTGAGACTTTCCCT \\
\hline pMH19R1 & TTGCGTTGCGCCTITACC \\
\hline pMH2OR3 & TCGAGACGATGCAGCGATAG \\
\hline pMH21R1 & TGGTTCTGGATCACTCGTCA \\
\hline $\mathrm{pMH} 22 \mathrm{R} 1$ & TTCGTCCTCCGTCTTGAGCA \\
\hline $\mathrm{pMH} 24 \mathrm{R} 2$ & CTCACCTCGTCGTACACACTA \\
\hline pMH25R1 & ATGCGGTTGACTTGACAGAT \\
\hline pMH26R2 & GGTTGACTCTGGATGTTGGA \\
\hline pMH27R1 & ATCTTGACGTCCTTGTCGAT \\
\hline pMH28R1 & GCGAATCGACCAGATCGTGT \\
\hline pMH29R1 & GTCCTTGCACCGCTTACACG \\
\hline pMH30R2 & GTAGAAGCGCAATGCGGTGG \\
\hline pMH32R2 & CAGATGCACGTCTTCCAGAT \\
\hline pMH33R1 & TCTGGTCTCGATTGCTCGTG \\
\hline pMH34R1 & CATCAGCCTCGTCTCCAGCA \\
\hline pMH35R3 & CATCATCAATGTCCTCGAAG \\
\hline pMH36R1 & GTCAGGATAGCGCCTGTCTG \\
\hline pMH37R1 & GTCCGGTACAGCGTGTCAAT \\
\hline
\end{tabular}

Primer named pgpdA was used in combination with the gene specific primers.

\section{Cultivation of $T$. reesei in shake flasks}

T. reesei QM9414 and representative clones from transformations of each of the regulatory factor constructs were cultivated on medium containing $4 \%$ lactose (Fagron), 2\% spent grain extract, $7.6 \mathrm{~g} / \mathrm{l}\left(\mathrm{NH}_{4}\right)_{2} \mathrm{SO}_{4}, 15.0$ $\mathrm{g} / \mathrm{KH}_{2} \mathrm{PO}_{4}, 2.4 \mathrm{mM} \mathrm{MgSO} 4.7 \mathrm{H}_{2} \mathrm{O}, 4.1 \mathrm{mM} \mathrm{CaCI} \cdot \mathrm{H}_{2} \mathrm{O}$, $3.7 \mathrm{mg} / \mathrm{l} \mathrm{CoCI} \mathrm{Cl}_{2}, 5 \mathrm{mg} / \mathrm{l} \mathrm{FeSO}{ }_{4} .7 \mathrm{H}_{2} \mathrm{O}, 1.4 \mathrm{mg} / \mathrm{l} \mathrm{ZnSO}_{4}$. $7 \mathrm{H}_{2} \mathrm{O}$ and $1.6 \mathrm{mg} / \mathrm{MnSO}_{4} .7 \mathrm{H}_{2} \mathrm{O}$, pH adjusted to 5.2 with $\mathrm{KOH}$. The culture medium was inoculated with $2 \times 10^{7}$ spores per $200 \mathrm{ml}$ of the medium, and grown at $28^{\circ} \mathrm{C}$ in conical flasks with shaking at $250 \mathrm{rpm}$ for 10 days. The strains were cultivated in triplicate. Samples were collected after 3, 5, 7 and 9 or 10 days of cultivation. For RNA isolation, mycelium was collected by filtering the samples, and the mycelium was washed with equal volume of $0.7 \% \mathrm{NaCl}$, frozen immediately in liquid nitrogen and stored at $-80^{\circ} \mathrm{C}$. For measurement of the biomass dry weight, the filtered and washed mycelium samples were dried at $105^{\circ} \mathrm{C}$ to constant weight $(24 \mathrm{~h})$. Filtered culture media was used for enzymatic assays and for measuring $\mathrm{pH}$.

\section{Enzyme assays}

Cellulase activity against the MUL substrate, CBHI and EGI activity was determined by detecting the fluorescent hydrolysis product methylumbelliferone released from the substrate MUL (Sigma-Aldrich, Steinheim, Germany) as described in [53]. The combined activity of EGI and CBHI was measured by inhibiting $\beta$-glucosidase activity with glucose. EGI activity was measured by adding cellobiose to inhibit CBHI and glucose to inhibit $\beta$-glucosidase. CBHI activity was deduced by subtracting EGI activity from the combined CBHI and EGI activity. Endo- $\beta-1.4-$ xylanase activity was assayed using $1.0 \%$ birch glucuronoxylan as a substrate [54]. The released reducing sugars were detected with 2-hydroxy-3,5-dinitrobenzoic acid. Pure xylose (Sigma-Aldrich) was used as a standard.

\section{Northern analysis}

Total RNA was isolated from the mycelium samples using the Trizol $^{\text {TM }}$ Reagent (Gibco BRL, Carlsbad, California, USA), essentially according to manufacturer's instructions. Northern blotting and hybridization on nitrocellulose filters (Hybond N, GE Healthcare) were carried out according to standard procedures [50]. Fragments of the genes to be analyzed were PCR amplified from the genomic DNA and used as probes in the Northern analysis. The signals in the northern blots were quantified using a phosphorimager (Typhoon imager, GE Healthcare), and the signals were normalized with those of actin.

\section{Quantitative PCR}

Total RNA was isolated from the mycelial samples of three parallel cultivations collected at the cultivation time

Table 5 Primers for the quantitative PCR analysis

\begin{tabular}{lll}
\hline Gene & $\mathbf{5}$ ' primer & 3' primer \\
\hline cbh1 & GCGGATCCTCTTTCTCAG & ATGTTGGCGTAGTAATCATCC \\
\hline cbh2 & TCCTGGTTATTGAGCCTGAC & GCAACATTTGAAGGTTCAG \\
\hline egl1 & GTCTACTACGAACTCGAC & GTAGTAGTCGTTGCTATACTG \\
\hline bgl1 & GCCTCCAAGATCAGCTATCC & ACCTCCTCACCGATGAACTG \\
\hline$x y n 1$ & AAACTACCAAACTGGCGG & TTGATGGGAGCAGAAGATCC \\
\hline$x y n 2$ & CGGCTACTTCTACTCGTACTG & TTGATGACCTTGTTCTTGTG \\
\hline xyn3 & TACAAGGGCAAGATTCGTG & ACTGGCTTCCAATACCGT \\
\hline axe1 & TAAAGCAGCAATCTTCATGG & GCAGTAAGACTTGATCTTGG \\
\hline bxl1 & GTCACTCTTCCAAGCTCAG & ATCGTTACCTCTTCTCCCA \\
\hline$x y r 1$ & GAGTATCAGCGCAACTTAGCA & CATCGGTATAGTGCAAGAAGCTC \\
\hline sar1 & TCTCCACCCTACTTCTGAG & CTTGTTGCCCAGGATGAC \\
\hline
\end{tabular}


points 3 and 5 days using Trizol ${ }^{\mathrm{me}}$ Reagent (Gibco BRL), essentially according to manufacturer's instructions. Single stranded cDNA was synthesized using a QuantiTect Reverse Transcription Kit (Qiagen, Hilden, Germany), with $1.5 \mu \mathrm{g}$ of total RNA as a template. The cDNA samples were diluted 1:10 to 1:50 and quantitative PCR reactions of two technical replicates were performed using a LightCycler 480 SYBR Green I Master Kit (Roche, Mannheim, Germany) according to the instructions of the manufacturer. The instrument used for quantitative PCR was Light Cycler 480 II and the results were analyzed with LightCycler 480 Software release 1.5.0. (version 1.5.0.39) using sar1 signal for normalization. The primers used in the quantitative PCR are listed in Table 5.

\section{Additional files}

Additional file 1: Transcriptional profiling data of the putative regulatory genes. Gene identifiers are as in T. reesei database version 2.0. Functional Interpro domain identifiers are as in InterPro database. Fold changes (log2 scale compared to uninduced control culture at a corresponding time point), signal intensities (log2 scale) and significance test ( $R$ package limma, $P<0.01$, log2 fold change $>0.4$ ) are shown for the genes. 1 indicates induction and -1 repression. The intensity of the red color and blue color indicates the strength of positive and negative fold changes, respectively. Color scales of yellow, red and green indicate different intensities of signals, red represents the strongest signals and green the weakest signals. AV1, 1\% Avicel cellulose; AV0.75, 0.75\% Avicel cellulose; $\mathrm{BE}$, enzymatically hydrolyzed steam-exploded bagasse; $\mathrm{BO}$, ground bagasse; BS, steam-exploded bagasse; SO, sophorose; SP, steam-exploded spruce; $\mathrm{WH}$, steam-exploded wheat straw; $\mathrm{XB}$, birch xylan; $\mathrm{XO}$, oat spelt xylan

Additional file 2: Production of total proteins and cellulase and xylanase activity by the recombinant strains at different time points of the cultivation. Results are shown for each strain volumetrically (nkat/l) and per biomass dry weight (nkat/g). The values are means of three biological replicates. Error bars show the standard error of the mean. BGL, $\beta$-glucosidase activity; CBHI, cellobiohydrolase activity; EGl, endoglucanase activity; MUL, total cellulase activity measured against the substrate 4-methylumbelliferyl- $\beta$-D-lactoside; XYN, xylanase activity.

Additional file 3: Results of Southern hybridizations. Position of the molecular weight size marker is shown as kb on the left. The restriction enzymes used for the digestion in the analysis are indicated by the letters: A, Ncol + BstXl; B, Bglll; C, Spel + Bcll; D, Clal + BamHI; E, Sacl; F, Nael; G, Clal + Xbal; H, SnaBl + Xbal; I, Stul; J, Sacl; K, Stul; L, Xmnl; M, BstEll; N, Sspl; O, Stul; P, Sspl; Q, Stul. For Del77513 strain two different probes were used: hygromycin selection marker (hph) open reading frame ( $\mathrm{N}$ and $O$ ) and fragment of the gene 77513 open reading frame ( $P$ and $Q$ ).

Additional file 4: Results of Northern hybridizations. Northern blot analysis of the expression of the candidate regulatory genes in the recombinant strains. (A) mRNA signals of genes 123668, 80291, 74765, 122523, 66966 and 64608 in cultures of the strains harboring the corresponding overexpression cassettes pMH18, pMH20, pMH25, pMH29, pMH35 and pMH36, respectively, are shown on the top. The mobility of the transcript encoded by the overexpression construct is indicated by an arrow in the blot. Samples collected after 3 days of cultivation (two biological replicates) were analyzed. The northern hybridization signal of actin and staining of total RNA with the SYBR Green II in the same gels are shown below each of the northern blots, as indicated. (B) mRNA signals of gene 77513 in cultures of overexpression strains pMH15 and pMH15(S), and in the Del77513 strain. Samples collected after 3 and 5 days of cultivation (two biological replicates) were analyzed. The northern hybridization signal of actin and staining of total RNA with the SYBR Green II in the same gel are shown below, as indicated. (C) Signal fold change of the northern signals in the recombinant strain versus the control strain. Signal intensities were normalized using the actin signal.

Additional file 5: pMS204 vector with hygromycin resistance gene and gateway cloning cassette under gpdA promoter and trpC terminator. AmpR, ampicillin resistance gene; attR1/attR2, att sites for recombination; $\mathrm{ccdB}, \mathrm{ccdB}$ gene for negative selection; $\mathrm{CmR}$,

chloramphenicol resistance gene; hph, hygromycin resistance gene; MCS, multiple cloning site; ORI, origin of replication.

\section{Abbreviations}

CAZy: carbohydrate active enzyme; $\mathrm{CBHI}$ : cellobiohydrolase 1; EGl: endoglucanase 1; MUL: 4-methylumbelliferyl- $\beta$-D-lactoside; ORF: open reading frame; $P C R$ : polymerase chain reaction.

\section{Competing interests}

The authors declare that they have no competing interests.

\section{Authors' contributions}

$\mathrm{MH}$ carried out cloning of the genes, participated in the construction and cultivation of the recombinant strains, enzymatic activity measurements and quantitative PCR analysis, carried out fungal cultivations and microarray detection of the expression signals for the second cultivation set, and drafted the manuscript. MJV carried out the Southern and northern hybridizations. AWP participated in the cloning of the genes, construction and cultivation of the recombinant strains and enzymatic activity measurements. NA carried out quantitative PCR analysis of transcript levels. MA analyzed the transcriptome data from the chemostat cultivations. MV participated in the data analysis and constructed the deletion strain. MP and MS conceived of the study, and participated in its design and coordination. TMP participated in the design and coordination of the study, carried out microarray data analysis including the selection of the candidate genes, and helped to draft the manuscript. All authors read and approved the final manuscript.

\section{Acknowledgements}

Aili Grundström, Riitta Nurmi, Hanna Kuusinen, Seija Nordberg, Riitta Lampinen and Tuuli Teikari are acknowledged for extremely skillful technical assistance. The work was funded by the VIT Biorefinery theme, the European Commission (the 6th Framework Programme, contract No. 019882), the Finnish Funding Agency for Technology and Innovation, Tekes (decision 40282/08), and Academy of Finland (decision no. 133455).

Received: 5 July 2013 Accepted: 14 January 2014 Published: 28 January 2014

\section{References}

1. Schuster A, Schmoll M: Biology and biotechnology of Trichoderma. Appl Microbiol Biotechnol 2010, 87(3):787-799.

2. Penttilä M, Limón C, Nevalainen H: Molecular biology of Trichoderma and biotechnological applications. In Mycology, Handbook of Fungal Biotechnology. Volume 20. 2nd edition. Edited by Arora DK. New York: Marcel Dekker; 2004:413-427.

3. Saloheimo M, Pakula TM: The cargo and the transport system: secreted proteins and protein secretion in Trichoderma reesei (Hypocrea jecorina). Microbiology 2012, 158(1):46-57.

4. Cantarel BL, Coutinho PM, Rancurel C, Bernard T, Lombard V, Henrissat B: The carbohydrate-active enzymes database (CAZy): an expert resource for glycogenomics. Nucleic Acids Res 2009, 37(suppl 1):D233-D238.

5. Carbohydrate Active Enzymes database. [http://www.cazy.org/]

6. Foreman PK, Brown D, Dankmeyer L, Dean R, Diener S, Dunn-Coleman NS, Goedegebuur F, Houfek TD, England GJ, Kelley AS, Meerman HJ, Mitchell T, Mitchinson C, Olivares HA, Teunissen PJM, Yao J, Ward M: Transcriptional regulation of biomass-degrading enzymes in the filamentous fungus Trichoderma reesei. J Biol Chem 2003, 278(34):31988-31997.

7. Martinez D, Berka RM, Henrissat B, Saloheimo M, Arvas M, Baker SE, Chapman J, Chertkov O, Coutinho PM, Cullen D, Danchin EGJ, Grigoriev IV, Harris P, Jackson M, Kubicek CP, Han CS, Ho I, Larrondo LF, de Leon AL, Magnuson JK, Merino S, Misra M, Nelson B, Putnam N, Robbertse B, Salamov AA, Schmoll M, Terry A, Thayer N, Westerholm-Parvinen A, et al: Genome 
sequencing and analysis of the biomass-degrading fungus Trichoderma reesei (syn. Hypocrea jecorina). Nat Biotech 2008, 26(5):553-560.

8. Häkkinen M, Arvas M, Oja M, Aro N, Penttilä M, Saloheimo M, Pakula T: Re-annotation of the CAZy genes of Trichoderma reesei and transcription in the presence of lignocellulosic substrates. Microb Cell Fact 2012, 11(1):134

9. Aro N, Pakula T, Penttilä M: Transcriptional regulation of plant cell wall degradation by filamentous fungi. FEMS Microbiol Rev 2005, 29(4):719-739.

10. Kubicek C, Mikus M, Schuster A, Schmoll M, Seiboth B: Metabolic engineering strategies for the improvement of cellulase production by Hypocrea jecorina. Biotechnol Biofuels 2009, 2(1):19.

11. Adav SS, Ravindran A, Chao LT, Tan L, Singh S, Sze SK: Proteomic analysis of $\mathrm{pH}$ and strains dependent protein secretion of Trichoderma reesei. J Proteome Res 2011, 10(10):4579-4596.

12. Schmoll M, Esquivel-Naranjo EU, Herrera-Estrella A: Trichoderma in the light of day - physiology and development. Fungal Genet Biol 2010, 47(11):909-916.

13. Pakula TM, Salonen K, Uusitalo J, Penttilä M: The effect of specific growth rate on protein synthesis and secretion in the filamentous fungus Trichoderma reesei. Microbiology 2005, 151(1):135-143.

14. Arvas M, Pakula T, Smit B, Rautio J, Koivistoinen H, Jouhten P, Lindfors E, Wiebe M, Penttilä M, Saloheimo M: Correlation of gene expression and protein production rate - a system wide study. BMC Genomics 2011, 12:616.

15. Abrahao Neto J, Rossini CHB, El-Gogary S, Henrique-Silva F, Crivellaro O, El-Dorry $\mathrm{H}$ : Mitochondrial functions mediate cellulase gene expression in Trichoderma reesei. Biochemistry 1995, 34(33):10456-10462.

16. Pakula TM, Laxell M, Huuskonen A, Uusitalo J, Saloheimo M, Penttilä M: The effects of drugs inhibiting protein secretion in the filamentous fungus Trichoderma reesei. J Biol Chem 2003, 278(45):45011-45020.

17. IImén M, Thrane C, Penttilä M: The glucose repressor gene cre1 of Trichoderma: isolation and expression of a full-length and a truncated mutant form. Mol Gen Genet MGG 1996, 251(4):451-460.

18. Stricker AR, Grosstessner-Hain K, Wurleitner E, Mach RL: Xyr1 (Xylanase Regulator 1) regulates both the hydrolytic enzyme system and D-Xylose metabolism in Hypocrea jecorina. Eukaryot Cell 2006, 5(12):2128-2137.

19. Aro N, Saloheimo A, Ilmén $M$, Penttilä $M$ : ACEll, a novel transcriptional activator involved in regulation of cellulase and xylanase genes of Trichoderma reesei. J Biol Chem 2001, 276(26):24309-24314.

20. Zeilinger SZ, Ebner AE, Marosits TM, Mach RM, Kubicek CK: The Hypocrea jecorina HAP 2/3/5 protein complex binds to the inverted CCAAT-box (ATTGG) within the cbh2 (cellobiohydrolase II-gene) activating element. Mol Genet Genomics 2001, 266(1):56-63.

21. Saloheimo A, Aro N, IImén M, Penttilä M: Isolation of the ace1 gene encoding a Cys2-His2 transcription factor involved in regulation of activity of the cellulase promoter $c b h 1$ of Trichoderma reesei. J Biol Chem 2000, 275(8):5817-5825.

22. Aro N, Ilmén M, Saloheimo A, Penttilä M: ACEI of Trichoderma reesei is a repressor of cellulase and xylanase expression. Appl Environ Microbiol 2003, 69(1):56-65.

23. Colabardini AC, Humanes AC, Gouvea PF, Savoldi M, Goldman MHS, Kress MRZ, Bayram Ö, Oliveira JVC, Gomes MD, Braus GH, Goldman GH: Molecular characterization of the Aspergillus nidulans fbxA encoding an F-box protein involved in xylanase induction. Fungal Genet Biol 2012, 49(2):130-140.

24. Jonkers W, Rep M: Mutation of CRE1 in Fusarium oxysporum reverts the pathogenicity defects of the FRP1 deletion mutant. Mol Microbiol 2009, 74(5):1100-1113.

25. Coradetti ST, Craig JP, Xiong Y, Shock T, Tian C, Glass NL: Conserved and essential transcription factors for cellulase gene expression in ascomycete fungi. Proc Natl Acad Sci 2012, 109(19):7397-7402.

26. Nitta M, Furukawa T, Shida Y, Mori K, Kuhara S, Morikawa Y, Ogasawara W: A new Zn(II)2Cys6-type transcription factor BgIR regulates $\beta$-glucosidase expression in Trichoderma reesei. Fungal Genet Biol 2012, 49(5):388-397.

27. Seiboth B, Karimi RA, Phatale PA, Linke R, Hartl L, Sauer DG, Smith KM, Baker SE, Freitag M, Kubicek CP: The putative protein methyltransferase LAE1 controls cellulase gene expression in Trichoderma reesei. Mol Microbiol 2012, 84(6):1150-1164.

28. Bioconductor, open source software for bioinformatics. [http://www bioconductor.org/

29. Kumar L, Futschik ME: Mfuzz: a software package for soft clustering of microarray data. Bioinformation 2007, 2(1):5-6,7.
30. Hunter S, Jones P, Mitchell A, Apweiler R, Attwood TK, Bateman A, Bernard T, Binns D, Bork P, Burge $S$, de Castro E, Coggill $P$, Corbett M, Das U, Daugherty L, Duquenne L, Finn RD, Fraser M, Gough J, Haft D, Hulo N, Kahn D, Kelly E, Letunic I, Lonsdale D, Lopez R, Madera M, Maslen J, McAnulla C, McDowall J, et al: InterPro in 2011: new developments in the family and domain prediction database. Nucleic Acids Res 2012, 40(D1):D306-D312.

31. Todd RB, Lockington RA, Kelly JM: The Aspergillus nidulans creC gene involved in carbon catabolite repression encodes a WD40 repeat protein. Mol Gen Genet 2000, 263(4):561-570.

32. Smyth GK, Michaud J, Scott HS: Use of within-array replicate spots for assessing differential expression in microarray experiments. Bioinformatics 2005, 21(9):2067-2075.

33. Nakazawa H, Okada K, Kobayashi R, Kubota T, Onodera T, Ochiai N, Omata $\mathrm{N}$, Ogasawara W, Okada H, Morikawa Y: Characterization of the catalytic domains of Trichoderma reesei endoglucanase I, II, and III, expressed in Escherichia coli. Appl Microbiol Biotechnol 2008, 81(4):681-689.

34. Kulmburg P, Mathieu M, Dowzer C, Kelly J, Felenbok B: Specific binding sites in the alcR and alcA promoters of the ethanol regulon for the CREA repressor mediating carbon cataboiite repression in Aspergillus nidulans. Mol Microbiol 1993, 7(6):847-857.

35. Tamayo EN, Villanueva A, Hasper AA, de Graaff LH, Ramón D, Orejas M: CreA mediates repression of the regulatory gene $x \ln R$ which controls the production of xylanolytic enzymes in Aspergillus nidulans. Fungal Genet Biol 2008, 45(6):984-99327.

36. Mach-Aigner AR, Pucher ME, Steiger MG, Bauer GE, Preis SJ, Mach RL: Transcriptional regulation of $x y r 1$, encoding the main regulator of the xylanolytic and cellulolytic enzyme system in Hypocrea jecorina. Appl Environ Microbiol 2008, 74:6554-6562.

37. Brakhage AA: Regulation of fungal secondary metabolism. Nat Rev Micro 2013, 11(1):21-32.

38. Karimi-Aghcheh R, Bok JW, Phatale PA, Smith KM, Baker SE, Lichius A, Omann M, Zeilinger S, Seiboth B, Rhee C, Keller NP, Freitag M, Kubicek CP: Functional analyses of Trichoderma reesei LAE1 reveal conserved and contrasting roles of this regulator. G3 (Bethesda) 2013, 3(2):369-378.

39. Metz B, Seidl-Seiboth $V$, Haarmann T, Kopchinskiy A, Lorenz P, Seiboth B, Kubicek CP: Expression of biomass-degrading enzymes is a major event during conidium development in Trichoderma reesei. Eukaryot Cell 2011, 10(11):1527-1535

40. Arvas M, Kivioja T, Mitchell A, Saloheimo M, Ussery D, Penttilä M, Oliver S. Comparison of protein coding gene contents of the fungal phyla Pezizomycotina and Saccharomycotina. BMC Genomics 2007, 8:325.

41. Porciuncula Jde O, Furukawa T, Shida Y, Mori K, Kuhara S, Morikawa Y, Ogasawara W: Identification of major facilitator transporters involved in cellulase production during lactose culture of Trichoderma reesei PC-3-7. Biosci Biotechnol Biochem 2013, 77(5):1014-1022.

42. Ivanova C, Bååth JA, Seiboth B, Kubicek CP: Systems analysis of lactose metabolism in Trichoderma reesei identifies a lactose permease that is essential for cellulase induction. PLoS One 2013, 8(5):e62631.

43. Ensembl database: [http://fungi.ensembl.org/index.html]

44. Stricker A, Mach R, de Graaff L: Regulation of transcription of cellulasesand hemicellulases-encoding genes in Aspergillus niger and Hypocrea jecorina (Trichoderma reesei). Appl Microbiol Biotechnol 2008, 78(2):211-220.

45. Trichoderma reesei database v2.0. [http://genome.jgi-psf.org/Trire2/Trire2. home.html]

46. Trichoderma reesei database v1.0. [http://genome.jgi-psf.org/trire1/trire1 home.html]

47. Punt PJ, Zegers ND, Busscher M, Pouwels PH, van den Hondel CA: Intracellular and extracellular production of proteins in Aspergillus under the control of expression signals of the highly expressed Aspergillus nidulans gpdA gene. J Biotechnol 1991, 17(1):19-33.

48. Mullaney E, Hamer J, Roberti K, Yelton MM, Timberlake W: Primary structure of the trpC gene from Aspergillus nidulans. Mol Gen Genet 1985, 199(1):37-45.

49. Penttilä M, Nevalainen $H$, Rättö M, Salminen E, Knowles J: A versatile transformation system for the cellulolytic filamentous fungus Trichoderma reesei. Gene 1987, 61(2):155-164.

50. Sambrook J, Fritsch E, Maniatis T: Molecular Cloning: A Laboratory Manual. 2nd edition. Cold Spring Harbor, NY: Cold Spring Harbor Laboratory; 1989.

51. Engler C, Kandzia R, Marillonnet S: A one pot, one step, precision cloning method with high throughput capability. PLoS One 2008, 3(11):e3647. 
52. Stewart $\mathrm{PE}$, Thalken R, Bono JL, Rosa P: Isolation of a circular plasmid region sufficient for autonomous replication and transformation of infectious Borrelia burgdorferi. Mol Microbiol 2001, 39(3):714-721.

53. Bailey MJ, Tähtiharju J: Efficient cellulase production by Trichoderma reesei in continuous cultivation on lactose medium with a computer-controlled feeding strategy. App/ Microbiol Biotechnol 2003, 62(2):156-162.

54. Bailey MJ, Biely P, Poutanen K: Interlaboratory testing of methods for assay of xylanase activity. J Biotechnol 1992, 23(3):257-270.

doi:10.1186/1754-6834-7-14

Cite this article as: Häkkinen et al.: Screening of candidate regulators for cellulase and hemicellulase production in Trichoderma reesei and identification of a factor essential for cellulase production. Biotechnology for Biofuels 2014 7:14.

\section{Submit your next manuscript to BioMed Central and take full advantage of:}

- Convenient online submission

- Thorough peer review

- No space constraints or color figure charges

- Immediate publication on acceptance

- Inclusion in PubMed, CAS, Scopus and Google Scholar

- Research which is freely available for redistribution 